\title{
Crowding Out or Crowding In? Economic Consequences of Financing Government Deficits
}

THE BUDGET DEFICIT of the federal government has emerged as a central focus in American public policy debate, attracting anxious attention from a variety of constituencies. The left now raises the specter of enlarged deficits in opposition to the increasingly audible calls for tax reduction, while the right continues to cite the same threat against new government spending initiatives. In either case the presumption of ill effects from a sustained deficit is an essential underpinning of the argument. The economic consequences of government deficits-usually alleged to be either inflationary (in the sense of raising prices), or deflationary (in the sense of depressing investment and hence economic growth), or both-today appear with unaccustomed urgency in discussions of hitherto unexciting policy issues. Several state legislatures have proposed a constitutional amendment prohibiting the federal government from spending beyond its

Note: I am grateful to David Jones, Angelo Melino, and Christopher Piros for research assistance; to Olivier J. Blanchard, Alan S. Blinder, James S. Duesenberry, Zvi Griliches, Michael J. Hamburger, Mervyn A. King, John Lintner, Reztlem H. Nalla, V. Vance Roley, Robert M. Solow, Stephen P. Taylor, and participants in BPEA for helpful comments on an earlier version; and to the National Science Foundation and the Alfred P. Sloan Foundation for research support. I also acknowledge at the outset the general guidance provided by James Tobin in two papers: "Money, Capital, and Other Stores of Value," American Economic Review, vol. 51 (May 1961), pp. 26-37, and "An Essay on Principles of Debt Management," in Fiscal and Debt Management Policies, prepared for the Commission on Money and Credit (Prentice-Hall, 1963), pp. 143-218. 
Table 1. Receipts and Expenditures of the Federal Government and as Percentage of Gross National Product, 1946-77

\begin{tabular}{|c|c|c|c|c|c|c|}
\hline \multirow[b]{2}{*}{$\begin{array}{c}\text { Calendar } \\
\text { year }\end{array}$} & \multicolumn{3}{|c|}{ Amount (billions of dollars) } & \multicolumn{3}{|c|}{ Percent of GNP } \\
\hline & Recelpts & $\begin{array}{c}\text { Expendi- } \\
\text { tures }\end{array}$ & $\begin{array}{l}\text { Surplus } \\
\text { or deficit }\end{array}$ & Receipts & $\begin{array}{c}\text { Expendi- } \\
\text { tures }\end{array}$ & $\begin{array}{c}\text { Surplus } \\
\text { or deficit }\end{array}$ \\
\hline 1946 & 39.1 & 35.6 & 3.5 & 18.7 & 17.0 & 1.7 \\
\hline 1947 & 43.2 & 29.8 & 13.4 & 18.6 & 12.8 & 5.8 \\
\hline 1948 & 43.2 & 34.9 & 8.3 & 16.7 & 13.5 & 3.2 \\
\hline 1949 & 38.7 & 41.3 & -2.6 & 15.0 & 16.0 & -1.0 \\
\hline 1950 & 50.0 & 40.8 & 9.2 & 17.5 & 14.3 & 3.2 \\
\hline 1951 & 64.3 & 57.8 & 6.5 & 19.5 & 17.5 & 2.0 \\
\hline 1952 & 67.3 & 71.1 & -3.7 & 19.4 & 20.5 & -1.1 \\
\hline 1953 & 70.0 & 77.1 & -7.1 & 19.1 & 21.1 & -2.0 \\
\hline 1954 & 63.7 & 69.8 & -6.0 & 17.4 & 19.1 & -1.7 \\
\hline 1955 & 72.6 & 68.1 & 4.4 & 18.2 & 17.1 & 1.1 \\
\hline 1956 & 78.0 & 71.9 & 6.1 & 18.5 & 17.1 & 1.4 \\
\hline 1957 & 81.9 & 79.6 & 2.3 & 18.5 & 18.0 & 0.5 \\
\hline 1958 & 78.7 & 88.9 & -10.3 & 17.5 & 19.8 & -2.3 \\
\hline 1959 & 89.8 & 91.0 & -1.1 & 18.5 & 18.7 & -0.2 \\
\hline 1960 & 96.1 & 93.1 & 3.0 & 19.0 & 18.4 & 0.6 \\
\hline 1961 & 98.1 & 101.9 & -3.9 & 18.7 & 19.5 & -0.7 \\
\hline 1962 & 106.2 & 110.4 & -4.2 & 18.8 & 19.6 & -0.8 \\
\hline 1963 & 114.4 & 114.2 & 0.3 & 19.2 & 19.2 & 0.0 \\
\hline 1964 & 114.9 & 118.2 & -3.3 & 18.1 & 18.6 & -0.5 \\
\hline 1965 & 124.3 & 123.8 & 0.5 & 18.1 & 18.0 & 0.1 \\
\hline 1966 & 141.8 & 143.6 & -1.8 & 18.8 & 19.1 & -0.2 \\
\hline 1967 & 150.5 & 163.7 & -13.2 & 18.9 & 20.6 & -1.7 \\
\hline 1968 & 174.7 & 180.6 & -5.8 & 20.1 & 20.8 & -0.7 \\
\hline 1969 & 197.0 & 188.4 & 8.5 & 21.1 & 20.1 & 0.9 \\
\hline 1970 & 192.1 & 204.2 & -12.1 & 19.6 & 20.8 & -1.2 \\
\hline 1971 & 198.6 & 220.6 & -22.0 & 18.7 & 20.7 & -2.1 \\
\hline 1972 & 227.5 & 244.7 & -17.3 & 19.4 & 20.9 & -1.5 \\
\hline 1973 & 257.9 & 264.8 & -6.9 & 19.8 & 20.3 & -0.5 \\
\hline 1974 & 288.6 & 299.3 & -10.7 & 20.5 & 21.2 & -0.8 \\
\hline 1975 & 286.2 & 356.8 & -70.6 & 18.8 & 23.4 & -4.6 \\
\hline 1976 & 331.4 & 385.2 & -53.8 & 19.5 & 22.7 & -3.2 \\
\hline 1977 & 374.5 & 422.6 & -48.1 & 19.8 & 22.4 & -2.6 \\
\hline
\end{tabular}

Source: U.S. Department of Commerce, national income and product accounts data.

receipts. In 1976 the victorious Democratic presidential candidate campaigned on a pledge to balance the government budget by 1980 .

Even a cursory look at the relevant historical data (see table 1) suggests why the furor has recently intensified so sharply. Since the mid1970s the federal government's excess of expenditures over receipts has 
strayed widely from the predominant pattern, experienced during the previous quarter century, of typically modest deficits that become somewhat less modest during recessions. As the U.S. economy sustained its most severe downturn since the 1930s, the deficit quickly rose to a postwar record level - both as a dollar magnitude and, more importantly, in relation to the underlying scale of economic activity. Even now that the economy has regained an activity rate about consistent with many economists' estimates of the "nonaccelerating-inflation rate of unemployment," the deficit remains above 2 percent of the gross national product. Moreover, campaign rhetoric to the contrary, there is little if any prospect of balancing the budget by the end of the decade.

Although the events surrounding the growing controversy over the government's budget deficit are sufficiently clear, there is not much agreement on the reasons why deficits are to be opposed. Several years ago, when a simple version of monetarism had its greatest hold on the thinking of decisionmakers in business and public policy, the reasoning was that deficits led to excessive money creation, which in turn raised prices. Once the huge deficits of 1975 and 1976 failed to elicit a comparable bulge in monetary growth, however, attention turned to the effects of deficits financed not by money but by issuing interest-bearing government debt. Since then most discussions of the subject have typically stemmed from either or both of two propositions about debt-financed deficits.

The first proposition is that even debt-financed deficits are inflationary because what matters for prices is not only the money stock but some combination of money plus the outstanding interest-bearing government debt (or perhaps merely the short-term component of that debt). In other words, according to this view, the stock of "money" that determines prices is really an "effective money" that includes instruments other than deposits and currency, and perhaps combines them with weights not restricted to zeroes or ones. Although years ago some economists advanced "total liquid asset" theories of income determination, ${ }^{1}$ recently this idea has not attracted much attention in the academic literature. ${ }^{2}$

1. See, for example, John G. Gurley, "The Radcliffe Report and Evidence," American Economic Review, vol. 50 (September 1960), pp. 672-700.

2. It is important to realize that a money-plus-bonds theory of nominal income (or price inflation) is not the same as a monetary theory of nominal income. For example, the growth of the narrowly defined money stock (currency plus demand deposits, $M_{1}$ ) has increased from 4.1 percent in 1975 to 7.9 percent during 1977, in comparison to 6.3 percent average growth for the preceding five years. By contrast, 
The second proposition, which is the focus of attention in this article, is that debt-financed deficits "crowd out" interest-sensitive, private-sector spending-in particular, investment in homes and in new productive capacity. Such a result, if true, would highlight two serious drawbacks to the traditional Keynesian notion of using deficit-causing fiscal policy as a stimulus of economic activity. That result would reduce (perhaps eliminate) the potency of fiscal policy for such stimulative purposes because government spending (or private spending induced by increased transfers or reduced taxes) would substitute for rather than add to private spending that would otherwise take place. And it would create a trade-off between any remaining short-run advantages of income expansion and the longer run benefits of productivity and growth associated especially with investment in new plant and equipment. The "crowding out" aspects of debtfinanced fiscal policy have undergone substantial analysis in the academic literature and have received widespread attention in the financial press and, more generally, among the government and business communities. Discussion along these lines abated somewhat after interest rates on private borrowing failed to rise during 1975 and 1976, but debate has recently intensified again, primarily because the deficit has remained large and fixed investment has been slow to regain vigor during the subsequent recovery. Fuller employment of the economy's resources and continuing large deficits are generating increasing concern that the crowding out that failed to materialize in 1975-76 could be a major problem in 1979-80.

In discussions of fiscal policy the term "crowding out" has several diverse meanings. Economists have long agreed that, if the supply of goods and services is fixed and resources fully employed, the government can claim more of the economy's output only by depriving the private sector of its use. Wholly apart from financial effects, in this case the crowding out of real private spending by price inflation (sometimes called "forced saving"), for example, is well recognized. Conversely, if resources are unemployed, by increasing utilization levels government spending can stimulate investment in productive capacity and thereby increase real

the stock of money plus outstanding treasury bills grew by 12.2 percent in 1974 but only 4.6 percent in 1977 , in comparison to its previous five-year average annual growth rate of 7.5 percent. Hence inferences drawn from a policy prescription of controlling money plus treasury bills would have diverged widely from inferences drawn from a policy of controlling money. 
private spending also. Such increases can follow, for example, from the response of the demand for capital stock to the observed or expected demand for final product, and the Congressional Budget Office has described such accelerator-based effects as "crowding in."3 Both these arguments for crowding out or crowding in focus in the first instance on real-sector effects associated with the additional government spending and not on the means of financing that spending. Indeed, the direction of these effects follows even if the additional spending is financed by taxes.

By contrast, much of the recent interest in the possibility of crowding out has explicitly focused not merely on deficit spending but more specifcally, given the experience of the mid-1970s, on deficits financed by issuing interest-bearing debt rather than money. The literature to date has distinguished two different ways in which such "financial crowding out" can occur: one associated with the demand for money for transactions purposes, and one with wealth effects on portfolio behavior. In either case, "financial crowding out" can take place independently of "real crowding out," and therefore can occur even if the economy is at less than full employment. Hence the financial crowding out potentially represents an even stronger argument against deficit spending for expansionary purposes. It is primarily the effect associated with financing the government deficit, especially the presumed consequences for private investment spending, that has recently attracted so much attention.

The objective of this article is to show that the prevailing view of the economic consequences of financing government deficits, as expressed in recent economic literature and policy debates, reflects serious misunderstandings. Debt-financed deficits need not crowd out any private investment, and may even crowd in some. And the reasons for this underscore the potential importance of a policy tool that economists both in and out of government have largely neglected for over a decade-debtmanagement policy. To focus sharply on financial crowding out and keep it separate from the undisputed phenomena in the real sector noted above, this analysis assumes that there are unemployed resources in the economy and disregards any accelerator effects.

The first section examines both analytically and empirically the "transactions crowding out" associated since Hicks with the slope of the $L M$

3. Congressional Budget Office, Inflation and Unemployment: $A$ Report on the Economy, June 30, 1975 (GPO, 1976), pp. 57-58. 
curve. ${ }^{4}$ This section reviews the familiar $I S-L M$ model and the existing econometric evidence on the slope of the $L M$ curve. In interpreting this evidence the discussion raises the question of whether the potency of short-run crowding out tends to be overstated by a failure to distinguish among the several different interest rates central to the $I S-L M$ model.

The second section addresses the "portfolio crowding out" emphasized by Milton Friedman, ${ }^{5}$ and to date most rigorously analyzed by Blinder and Solow and by Tobin and Buiter. ${ }^{6}$ Using a model including three assets-money, government bonds, and real capital-the analysis shows that even the sign of the portfolio effect of bond issuing on private investment depends on the relative substitutabilities among these three assets in the public's aggregate portfolio. The well-known Blinder-Solow analysis, with its presumption of a negative effect, is simply the special case associated with the arbitrary (and rather implausible) assumption that government bonds and real capital are perfect substitutes. Because the question of whether or not the demand for money depends on portfolio wealth has become a key issue in assessing the empirical importance of portfolio crowding out, this section also presents econometric evidence indicating that money demand does indeed depend on wealth as well as income - in other words, that people hold money balances for both transactions and portfolio reasons. In addition, the discussion digresses briefly to show that including wealth in the money-demand function makes a large contribution to solving Goldfeld's missing money mystery, as well as to explaining Hamburger's proposed solution.?

The third section extends the model of portfolio crowding out to show that the crucial substitutabilities that make the difference between crowding out and crowding in are determined in part by the government's choice of debt instrument for financing the deficit. Hence when monetary

4. J. R. Hicks, "Mr. Keynes and the 'Classics'; A Suggested Interpretation," Econometrica, vol. 5 (April 1937), pp. 147-59.

5. See Friedman's response to Tobin in "Comments on the Critics," Journal of Political Economy, vol. 80 (September-October 1972), pp. 906-50.

6. Alan S. Blinder and Robert M. Solow, "Does Fiscal Policy Matter?" Journal of Public Economics, vol. 2 (November 1973), pp. 319-37; James Tobin and Willem Buiter, "Long-Run Effects of Fiscal and Monetary Policy on Aggregate Demand," in Jerome L. Stein, ed., Monetarism (Amsterdam: North-Holland, 1976; distributor, American Elsevier), pp. 273-309.

7. Stephen M. Goldfeld, "The Case of the Missing Money," BPEA, 3: 1976, pp. 683-730; Michael J. Hamburger, "Behavior of the Money Stock: Is There a Puzzle?" Journal of Monetary Economics, vol. 3 (July 1977), pp. 265-88. 
policy is unaccommodative, within limits debt-management policy can take its place in augmenting the potency of stimulative fiscal policy or in improving the otherwise fixed trade-off between short-run stimulation and investment for long-run growth.

A final section summarizes the implications of these findings for fiscal, monetary, and debt-management policies.

\section{Transactions Crowding Out}

The transactions crowding out associated with a government deficit financed by issuing nonmoney claims has been a standard part of the Keynesian fiscal policy analysis at least since Hicks' formalization of it in the $I S-L M$ model. In increasing the level of economic activity, the spending increase (or tax cut) that leads to the deficit also increases the demand for money for transactions purposes. If the supply of money remains fixed, and if the money market is to clear, then some other factor must generate a precisely offsetting decrease in money demand. If the public's demand for money balances is sensitive to the rate of interest because of portfolio considerations or simply because of the inventorytheoretic considerations applied to transactions balances by Baumol and Tobin, ${ }^{8}$ the required offset for money demand is brought about by an increase in "the interest rate" earned by nonmoney claims. However, because aggregate private spending depends negatively on the interest rate, the increase in the interest rate that clears the money market also erodes some of the income-expansionary effect of the initial fiscal policy action.

\section{THE IS-LM MODEL WITHOUT WEALTH EFFECTS}

Briefly retracing transactions crowding out in terms of the standard Hicks $I S-L M$ model will be useful both to facilitate a discussion of empirical magnitudes and to motivate the subsequent analysis of portfolio crowding out.

In linear form, the static equilibrium version of the underlying model

8. William J. Baumol, "The Transactions Demand for Cash: An Inventory Theoretic Approach," Quarterly Journal of Economics, vol. 66 (November 1952), pp. 545-56; James Tobin, "The Interest-Elasticity of Transactions Demand for Cash," Review of Economics and Statistics, vol. 38 (August 1956), pp. 241-47. 
includes a goods market consisting of a consumption function, an investment function (without accelerator effects), and a spending-income identity ${ }^{\circ}$

$$
\begin{aligned}
C & =c_{0}+c_{1}(Y-T), & & 0<c_{1}<1 \\
I & =i_{0}+i_{1} r, & & i_{1}<0 \\
Y & =C+I+G . & &
\end{aligned}
$$

It also includes a money market consisting of a money-demand function and a market-clearing equilibrium condition

$$
\begin{aligned}
& M^{D}=m_{0}+m_{1} Y+m_{2} r, \quad m_{1}>0>m_{2} \\
& M^{D}=M,
\end{aligned}
$$

where

$$
\begin{aligned}
C & =\text { private consumption spending } \\
G & =\text { government purchases of goods and services } \\
I & =\text { private investment spending } \\
M^{D} & =\text { demand for money } \\
M & =\text { supply of money } \\
r & =\text { "the interest rate" on nonmoney claims } \\
T & =\text { taxes } \\
Y & =\text { income (total spending). }
\end{aligned}
$$

Given unemployed resources, there is no representation of supply in the goods market, and goods prices are held constant and (for simplicity) normalized to unity.

When $G, T$, and $M$ are treated as exogenous, equations 1 through 5 suffice to determine $C, I, M^{D}, r$, and $Y$. The more compact $I S$ - $L M$ form of the model follows from solving 1 through 3 into a goods-market equilibrium or $I S$ curve relating $Y$ and $r$,

$$
Y=\frac{c_{0}+i_{0}-c_{1} T+G}{1-c_{1}}+\left(\frac{i_{1}}{1-c_{1}}\right) r
$$

9. Here, as well as elsewhere in this article, lowercase letters with subscripts are fixed coefficients in equations for economic variables indicated by the corresponding uppercase letters. For example, $c_{0}$ and $c_{1}$ are the coefficients in the consumption function $C ; i_{0}$ and $i_{1}$ are the coefficients in the investment function $I$. This convention is especially useful in the more complicated asset-demand systems that appear in the following sections. 
and likewise solving 4 and 5 into a money-market equilibrium or $L M$ curve,

$$
Y=\frac{M-m_{0}}{m_{1}}-\left(\frac{m_{2}}{m_{1}}\right) r .
$$

Because the $I S$ curve relates $Y$ negatively to $r$ while the $L M$ curve relates $Y$ positively to $r$, except for pathological values the model yields general equilibrium in the $(r, Y)$ space as shown in the diagram below by the intersection of curves $I S_{0}$ and $L M_{0}$ conditional on values $G_{0}, T_{0}$, and $M_{0}$.

In the absence of any crowding out, the effect on $Y$ of an increase in $G$ would be, from equation 6 , simply the partial derivative

$$
\frac{\partial Y}{\partial G}=\frac{1}{1-c_{1}}
$$

that is, the familiar "consumption multiplier." The diagram indicates this dependence of $Y$ on $G$ in the goods market alone by the rightward shift from curve $I S_{0}$ conditional on $G_{0}$ to curve $I S_{1}$ conditional on $G_{1}$. In place of the original equilibrium value $Y_{0}$, the partial equilibrium, conditional on holding the interest rate constant at $r_{0}$, is $Y^{\prime}>Y_{0}$. Because the pair $\left(Y_{0}, r_{0}\right)$ satisfied the money-market equilibrium condition and because $Y^{\prime} \neq Y_{0}$, however, the pair $\left(Y^{\prime}, r_{0}\right)$ cannot also satisfy that condition. Hence the point $\left(Y^{\prime}, r_{0}\right)$, which lies to the right of the $L M$ curve in the diagram, is not a point of general equilibrium.

To find the general equilibrium it is necessary to solve the $I S-L M$ model of 6 and 7 for its reduced-form equation for $Y$ as

$$
Y=\frac{\left(m_{2} c_{0}+m_{2} i_{0}-i_{1} m_{0}\right)-m_{2} c_{1} T+i_{1} M+m_{2} G}{m_{2}\left(1-c_{1}\right)+i_{1} m_{1}} .
$$

Thus the relevant total derivative expresses the effect of $G$ on $Y$ as

$$
\frac{d Y}{d G}=\frac{m_{2}}{m_{2}\left(1-c_{1}\right)+i_{1} m_{1}} .
$$

Because the denominator of 10 is unambiguously negative and the interest elasticity $m_{2}$ is nonpositive, the effect is positive as expected. Moreover, 10 clearly indicates two important aspects of transactions crowding out. First, if $m_{2}=0$ (that is, if money demand is interest inelastic), $G$ has no effect on $Y$. In graphical terms, 7 implies a vertical $L M$ curve at 


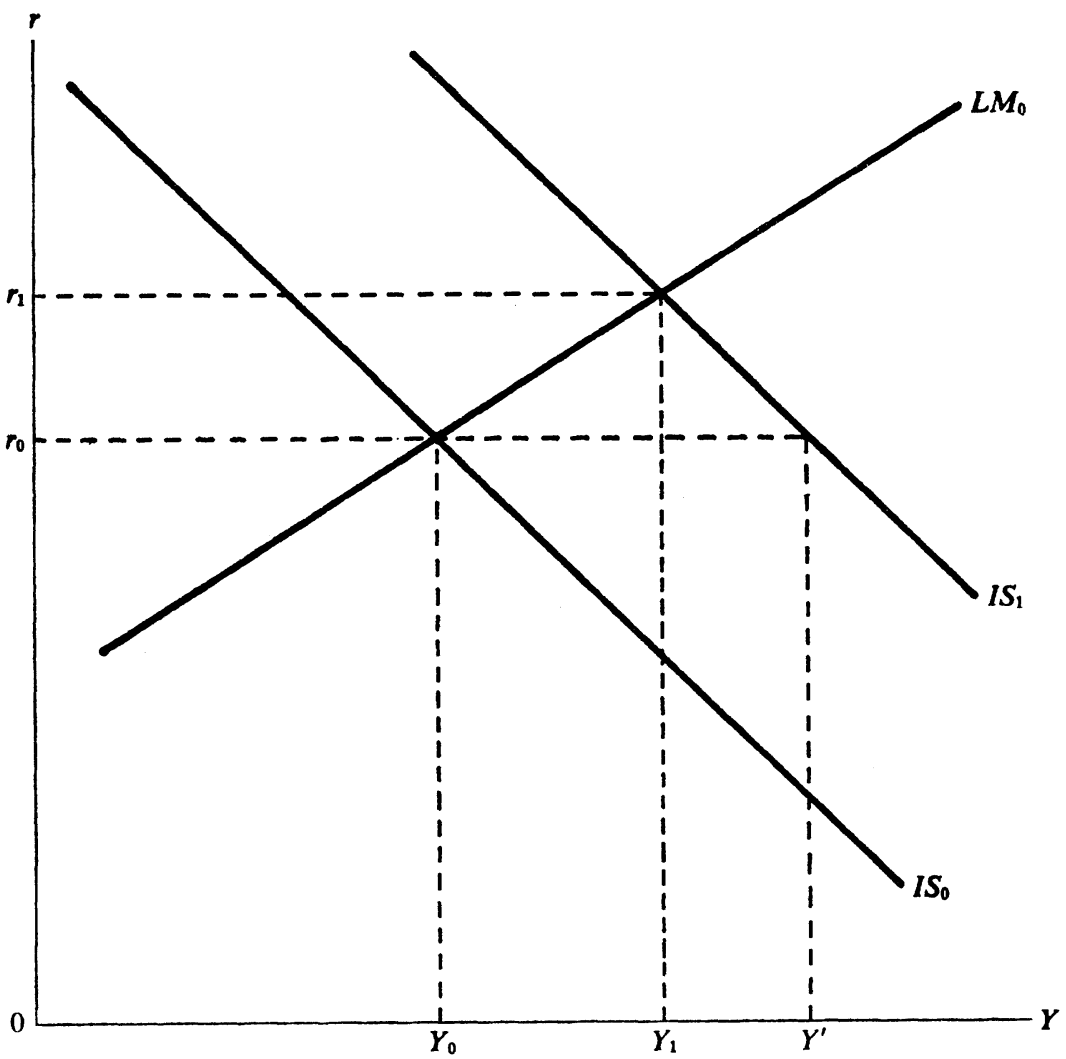

$Y=M-m_{0} / m_{1}$ if $m_{2}=0$, so that the only consequence of shifting $I S_{0}$ to $I S_{1}$ is a higher interest rate.

Second, given $m_{2} \neq 0$ (and given the other coefficient signs noted above), the total derivative in 10 is strictly less than the partial derivative in 8 as long as $i_{1} \neq 0$ (that is, investment is interest sensitive) and $m_{1} \neq 0$ (that is, money demand does depend on income, so that the constant interest rate leading to $Y^{\prime}$ in the diagram does not obtain). In graphical terms, the general equilibrium value $Y_{1}$ associated with the intersection of $L M_{0}$ and $I S_{1}$ must be strictly greater than $Y_{0}$ but less than $Y^{\prime}$ as long as the $I S$ curve is nonvertical and the $L M$ curve is nonhorizontal. Solving the model for the corresponding reduced-form equation for $r$,

$$
r=\frac{-\left[m_{0}\left(1-c_{1}\right)+m_{1}\left(c_{0}+i_{0}\right)\right]-m_{1} c_{1} T+\left(1-c_{1}\right) M-m_{1} G}{m_{2}\left(1-c_{1}\right)+i_{1} m_{1}}
$$


Table 2. Estimates of Interest and Income Elasticities from Various Versions of the IS-LM Model

Type of elasticity and version of model

Short-run value

Long-run value

Interest elasticity of real spending*

Friedman

Income elasticity of money demand

Goldfeld $\left(M_{1}\right)$

0.193

0.682

Friedman $\left(M_{2}\right)$

0.362

1.18

Hamburger $\left(M_{1}\right)$

0.110

1.00

Interest elasticity of money demand ${ }^{\mathrm{b}}$

Goldfeld $\left(M_{1}\right)$

$\begin{array}{ll}-0.064 & -0.226 \\ -0.0512 & -0.166 \\ -0.074 & -0.673\end{array}$

Friedman $\left(M_{2}\right)$

Hamburger $\left(M_{1}\right)$

$-0.074$

$-0.673$

Sources: Derived from models presented in the following papers: Benjamin M. Friedman, "The In efficiency of Short-Run Monetary Targets for Monetary Policy," BPEA, 2:1977, pp. 293-335; Stephen M. Goldfeld, "The Demand for Money Revisited," BPEA, 3:1973, pp. 577-638; and Michael J. Hamburger. "Behavior of the Money Stock: Is There a Puzzle?" Journal of Monetary Economics, vol. 3 (July 1977), pp. 265-88.

a. Taken from the directly estimated $I S$ curve in the Pirandello model which I presented in an earlier paper (Benjamin M. Friedman, "The Inefficiency of Short-Run Monetary Targets for Monetary Policy," $B P E A, 2: 1977$, pp. 293-335). In estimating this model I used an instrumental-variables procedure to derive consistent estimators given the endogeneity of both $Y$ and $r$.

b. $M_{1}$ indicates that money demand was measured by currency plus demand deposits; $M_{2}$ models used $M_{1}$ plus time deposits at commercial banks except negotiable certificates of deposit of $\$ 100,000$ or more.

actions crowding out-that is, the ratio of the total derivative in $\mathbf{1 0}$ to the partial derivative in 8 .

For purposes of estimating the magnitude of transactions crowding out it is essential to coordinate the interest rate used to measure the interest elasticity of money demand with that used to measure the interest elasticity of spending. Otherwise the implied $I S$ and $L M$ curves exist on graphs with different vertical axes, ${ }^{11}$ and their relative slopes are not comparable. Although the simplified $I S-L M$ model usually refers to "the interest rate" on nonmoney claims, in fact the yields earned on different claims behave differently. Moreover, it is well known that the interest elasticity estimated for the money-demand function typically depends on which interest rate(s) the equation includes. Specifically, money demand nearly always shows a small elasticity with respect to short-term interest rates-for example, the yields on time deposits and commercial paper as in the Goldfeld equation, or the yield on treasury bills as in the Pirandello

11. Analogously, if there were some shift in the relationship between income and transactions, the $I S$ and $L M$ curves would also refer to different horizontal axes. 
and examining the total derivative,

$$
\frac{d r}{d G}=\frac{-m_{1}}{m_{2}\left(1-c_{1}\right)+i_{1} m_{1}},
$$

confirms that the reason for $Y_{1}<Y^{\prime}$ is a rise in the interest rate from $r_{0}$ to $r_{1}$.

\section{EMPIRICAL MAGNITUDES AND SOME MULTIPLE-ASSET IMPLICATIONS}

How important is transactions crowding out likely to be in practice? The answer most frequently given invokes econometric evidence indicating a relatively steep $L M$ curve-that is, a relatively small interest sensitivity of money demand-to conclude that transactions crowding out is likely to be large in comparison with the effect of the underlying fiscal action. On closer inspection, however, this answer turns out to depend primarily on a failure to distinguish among the yields on distinct kinds of nonmoney claims.

Table 2 summarizes some short- and long-run parameter estimates, drawn from several sources, that are relevant for calculating the implied magnitude of transactions crowding out. ${ }^{10}$ In all cases the underlying equations have been estimated (for quarterly data) in logarithmic form, so that they can be directly interpreted in terms of percentage changes; conversion to dollar magnitudes in turn depends on the base chosen.

Table 3 presents a set of calculations, based on the parameter estimates in table 2 , of the effectiveness of fiscal policy after allowing for transactions crowding out. The summary statistic shown is the ratio of the general equilibrium effect of debt-financed government spending on income, including the allowance for transactions crowding out, to the corresponding partial-equilibrium, "goods-market-only" effect, excluding any trans-

10. Alternative, but also less transparent, ways of calculating this magnitude include simulating large nonlinear econometric models and estimating direct reduced forms. See, for example, Franco Modigliani and Albert Ando, "Impacts of Fiscal Actions on Aggregate Income and the Monetarist Controversy: Theory and Evidence," in Stein, Monetarism, pp. 17-42; and Leonall C. Andersen and Jerry L. Jordan, "Monetary and Fiscal Actions: A Test of Their Relative Importance in Economic Stabilization," Federal Reserve Bank of St. Louis, Review, vol. 50 (November 1968), pp. 11-24. 
Table 3. Estimates of the Effectiveness of Fiscal Policy after Allowance for Transactions Crowding Out

\begin{tabular}{lcc}
\hline $\begin{array}{c}\text { Money-demand } \\
\text { function }^{\mathrm{a}}\end{array}$ & Short-run value $^{\mathrm{b}}$ & Long-run value $^{\mathrm{b}}$ \\
\hline Goldfeld $\left(M_{1}\right)$ & 0.930 & 0.657 \\
Friedman $\left(M_{2}\right)$ & 0.849 & 0.448 \\
Hamburger $\left(M_{1}\right)$ & 0.876 & 0.796 \\
\hline
\end{tabular}

Sources: Estimated from text equations 8 and 10 and data in table 2. In all three sets of calculations the interest elasticity of spending is taken from the Pirandello model.

a. For explanation of the functions, see table 2 sources and notes.

b. Ratio of the total derivative in text equation 10 to the partial derivative in text equation 8 . See discussion of table in text.

model. Conversely, money demand generally shows a large elasticity with respect to long-term interest rates; an example is the yields on long-term government bonds and equities, as in the Hamburger equation.

In comparing one long-run equilibrium with another, it is plausible to assume that alternative nonmoney claims will exhibit identical movements in yields-apart from the important portfolio effects emphasized in the next section-so that this coordination problem does not arise in calculating the magnitude of long-run transactions crowding out. In the short run, however, the typical experience is that interest rates on long-term nonmoney claims are less volatile than those on short-term nonmoney claims. The diagram below illustrates the implication of this distinction for the calculation of the magnitude of short-run transactions crowding out by plotting two $L M$ curves, $L M_{0}\left(r_{L}\right)$ and $L M_{0}\left(r_{s}\right)$, which relate money demand to long-term and short-term interest rates, respectively. The $I S$ curves in the diagram, $I S_{0}$ and $I S_{1}$, both relate spending to long-term interest rates because the interest rate used to estimate the interest elasticity of spending shown in table 2 and used in all the calculations presented in table 3 is the yield on long-term corporate bonds. ${ }^{12}$ The correct short-run effect of the fiscal policy that shifts $I S_{0}$ to $I S_{1}$ is to raise income from $Y_{0}$ to $Y_{1}$, the intersection of the mutually consistent $I S_{1}\left(r_{L}\right)$ and $L M_{0}\left(r_{L}\right)$. Because

12. The usual argument for relating real spending to long-term interest rates is that, for reasons related to risk aversion, businesses tend to finance investment in plant and equipment with long-term liabilities, and households generally finance residential construction with long-term liabilities. For an argument that investment instead depends on a kind of short-term yield (though not on the measured yield on short-term assets like deposits or commercial paper), see Robert E. Hall, "Investment, Interest Rates, and the Effects of Stabilization Policies," BPEA, 1: 1977, pp. 61-103. 


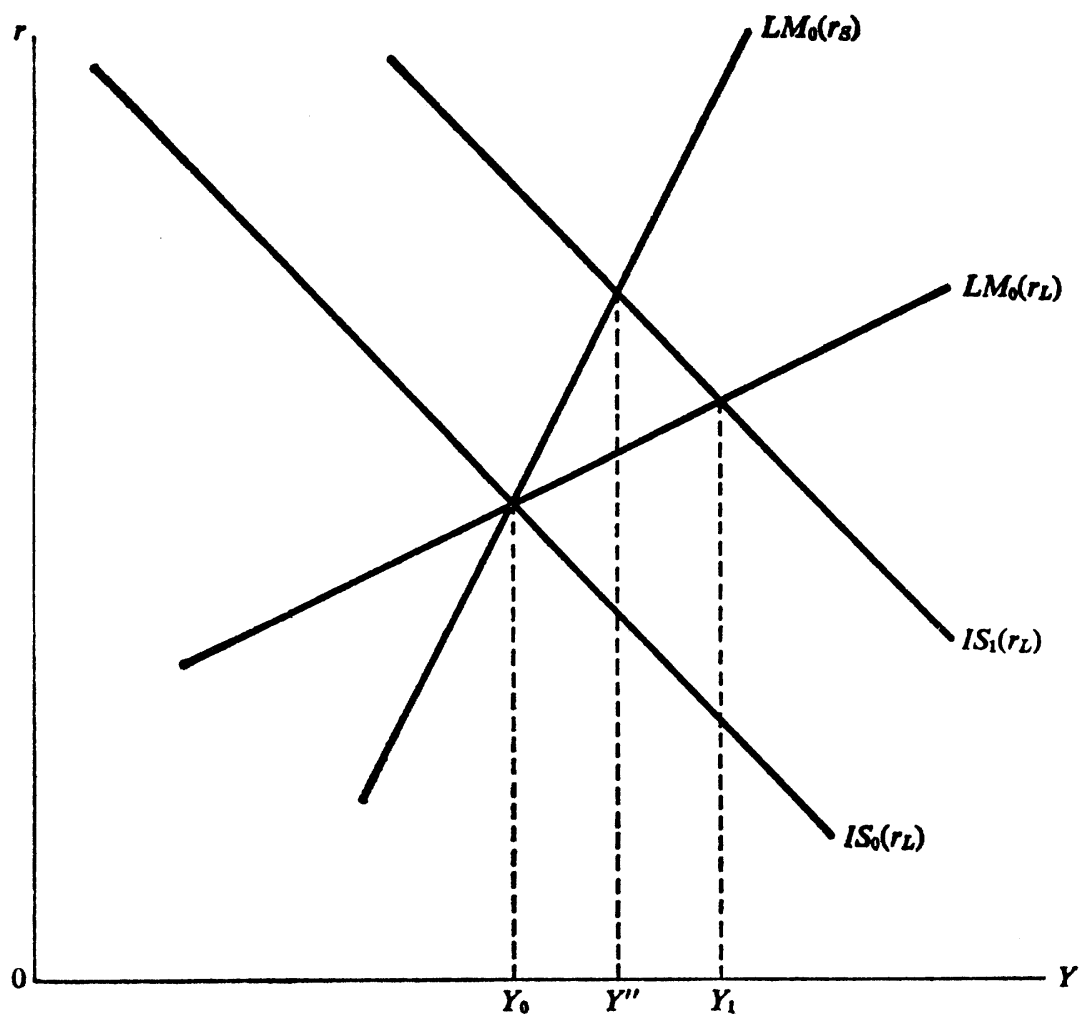

$L M_{0}\left(r_{S}\right)$ is steeper than $L M_{0}\left(r_{L}\right)$, the point $Y^{\prime \prime}$ at which $I S_{1}\left(r_{L}\right)$ and $L M_{0}\left(r_{s}\right)$ intersect underestimates the effectiveness of fiscal policy in the presence of transactions crowding out.

The equations in both the Goldfeld and the Pirandello models relate money demand to short-term interest rates, and thus are analogous to curve $L M\left(r_{s}\right)$. Hence some correction for the greater volatility of shortterm interest rates is necessary to render the calculation of the magnitude of short-run transactions crowding out comparable to point $Y_{1}$, rather than $Y^{\prime \prime}$, in the diagram. The calculations reported in table 3 use the Pirandello model's term-structure equation for this purpose. ${ }^{13}$ By contrast, Hamburger's equation relates money demand to long-term interest

13. The equation plausibly indicates a $\mathbf{0 . 2 6 5}$ short-run elasticity of the long-term interest rate with respect to the short-term rate. 
rates, so that it is already analogous to curve $L M_{0}\left(r_{L}\right)$, and hence with the $I S\left(r_{L}\right)$ slope yields the short-run transactions crowding out effect directly.

The first pair of calculations shown in table 3 is based on Goldfeld's $M_{1}$ demand equation. In the short run the $L M$ curve adjusted for the term structure is sufficiently flat to offset less than one-tenth of the effect on income (spending) associated with the rightward shift of the $I S$ curve. In the long run the interest elasticity of money demand increases more than does the income elasticity, and the interest elasticity of spending also becomes greater. Because of the steeper $L M$ and fiatter $I S$ curves, in the long run transactions crowding out offsets about one-third of the IS curve's rightward shift. The second pair of calculations, based on the Pirandello model's $M_{2}$ equation, indicates a somewhat greater crowding out effect because of the larger estimated income elasticity of $M_{2}$ demand. Fixing $M_{1}$ is not the same policy as fixing $M_{2}$ when their respective income elasticities differ-as most empirical estimates indicate. Finally, the pair of calculations based on Hamburger's $M_{1}$ demand function indicates about the same amount of crowding out in the short run, but noticeably less than both the Goldfeld and Pirandello equations in the long run, primarily because of the large estimated long-run interest elasticity.

All three calculations reported in table 3 indicate that transactions crowding out offsets only a small part of the expansionary effect of government spending, particularly in the short run. A key reason for the contrast between this result and the presumptions based on notions of steepness of the $L M$ curve probably stems from a failure to consider the implications of the different measured elasticities of money demand with respect to short- versus long-term interest rates. ${ }^{14}$ In the long run, transactions crowding out is more powerful, but even then one-half or more of the expansionary effect remains.

\section{SUMMARY}

Several useful conclusions emerge from a review of the theory and evidence pertaining to transactions crowding out.

There is no disagreement that, with unaccommodative monetary

14. Without the term-structure correction the short-run estimates in table 3 would be 0.778 for Goldfeld's equation and 0.599 for the Pirandello model's equation. 
policy, transactions crowding out offsets some part of the effect of fiscal policy on income. Only with a vertical IS curve will it offset none of the effect, and only with a vertical $L M$ curve will it offset all of it.

In the short run the offset is probably small, say, of the order of onetenth; in the long run it is almost certainly greater, say, of the order of one-third or more.

Because of the different income elasticities of the public's demands for time and demand deposits, the offset is greater if monetary policy controls $M_{2}$ than if it controls $M_{1}$.

\section{Portfolio Crowding Effects ${ }^{15}$}

If transactions crowding out does not vitiate the intended effect of a fiscal policy action accompanied by unaccommodative monetary policy, the question of the potency of fiscal policy with a fixed money stock hinges (from a financial perspective) on portfolio crowding out. Here the explicit portfolio effects associated with financing the deficit (or disposing of a surplus) by issuing (or retiring) interest-bearing government debt assume primary importance. ${ }^{16}$ The underlying mechanisms are both more complicated and less familiar than those that give rise to transactions crowding out. Introducing wealth into the model is an essential first step. Beyond wealth effects per se, however, it is necessary to introduce a more complete representation of the public's asset-holding preferences.

It is an anomaly that the economic consequences of the resulting portfolio effects have come to be conventionally known as crowding out. In fact, the net result may be either crowding out or crowding in. In other words, bond financing of government deficits may either increase or decrease private investment spending. The incorrect but nonetheless currently widespread view that a decrease in investment is the only possible result is due to the failure to consider adequately the public's portfolio

15. Since writing this paper I have seen a paper by Cohen and McMenamin that overlaps some of the analysis of this section; see Darrel Cohen and J. Stuart McMenamin, "The Role of Fiscal Policy in a Financially Disaggregated Macroeconomic Model," Journal of Money, Credit, and Banking, vol. 10 (August 1978), pp. 322-36.

16. Money, or the monetary base when it is distinguished from money, also constitutes a part of the government's debt. Unless specified to the contrary, however, the term "debt" in this article means interest-bearing debt. 
behavior. Clearing up this misunderstanding is an important precursor to sensible analysis of fiscal policy.

\section{CROWDING OUT OR CROWDING IN}

Wealth effects exert important and long-recognized influences on economic behavior in both the goods market and the asset markets. First, in the goods market the idea of positive wealth effects on consumption dates at least to Pigou, and Keynes argued for an analogous effect on investment. ${ }^{17}$ More recently Modigliani and others have formalized this relationship in the "life cycle" model, and both he and Tobin and Dolde have elaborated the associated linkages and explored the empirical evidence. ${ }^{18}$ For purposes of the current discussion it is sufficient simply to use an $I S$ curve that is analogous to 6 but that incorporates the wealth effects operating within the goods market,

$$
Y=y_{0}+y_{1} G+\left(1-y_{1}\right) T+y_{2} r+y_{3} W, \quad y_{3}>0>y_{2}, y_{1}>1,
$$

where $W$ is total real wealth held by the private sector. ${ }^{19}$

A minimal model for the analysis of portfolio crowding out includes three distinct components of private wealth,

$$
W=M+B+K,
$$

where

$$
\begin{aligned}
M= & \text { the money stock } \\
B= & \text { the outstanding stock of interest-bearing (that is, nonmoney) } \\
& \quad \text { government bonds } \\
K= & \text { the outstanding stock of real capital. }
\end{aligned}
$$

The continued assumption of constancy of goods prices (with the price

17. A. C. Pigou, "The Value of Money," Quarterly Journal of Economics, vol. 32 (November 1917), pp. 38-65; John Maynard Keynes, The General Theory of Employment, Interest and Money (Harcourt, Brace, 1936).

18. Franco Modigliani, "Monetary Policy and Consumption: Linkages via Interest Rate and Wealth Effects in the FMP Model," and James Tobin and Walter Dolde, "Wealth, Liquidity and Consumption," both in Consumer Spending and Monetary Policy: The Linkages, Proceedings of a Monetary Conference, 1971 (Federal Reserve Bank of Boston, n.d.), pp. 9-84 and 99-146, respectively.

19. Like 6, equation 13 exhibits a unit balanced-budget multiplier; this result follows from the partial-equilibrium, goods-market-only nature of both 6 and 13 . 
level normalized at unity) avoids the need to distinguish between real and nominal magnitudes. ${ }^{20}$ The key source of variation of wealth for purposes of the current discussion is the government budget constraint emphasized by Christ and Silber, ${ }^{21}$

$$
G-T=d M+d B
$$

A useful simplifying assumption underlying the (implicitly one-period) static equilibrium analysis, comparable to that of the first section of this article, is that the initial equilibrium corresponding to $I S_{0}$ and $L M_{0}$ in the first diagram is characterized by a balanced budget, $G=T$, and that taxes remain unchanged. ${ }^{22}$ Hence any government spending increase (or decrease) $d G$ precisely equals the combination $d M+d B$ that finances it. A further simplifying assumption, again in the one-period static equilibrium context, is that $K$ is fixed, so that $d W$ also equals $d M+d B$. In

20. The analysis in this article implicitly assumes that the public regards all the increase in the stock of outstanding government bonds as a net increase in wealth, because 14 omits "human wealth," which would fall with anticipations of additional taxes for debt service. By contrast, Barro has argued that human wealth would fall enough to leave total wealth unchanged; see Robert J. Barro, "Are Government Bonds Net Wealth?" Journal of Political Economy, vol. 82 (November-December 1974), pp. 1095-1117. The standard arguments against this view appeal to the imperfections in the credit market faced by nearly all taxpayers, as well as by intergenerational nonneutralities. Rewriting 14 so that movements in human wealth offset some fraction of changes in the stock of bonds would alter none of my substantive conclusions. Moreover, by providing empirical evidence that the pricing of marketable assets is independent of returns to human (nonmarketable) wealth, Fama and Schwert suggest that the asset-market effects, which are at the heart of the analysis here, would remain unaltered even if movements in human wealth offset all changes in the stock of bonds; see Eugene F. Fama and G. William Schwert, "Human Capital and Capital Market Equilibrium," Journal of Financial Economics, vol. 4 (January 1977), pp. 95-125. Yet a further generalization would be to allow for bond valuation changes by writing $B$ as a function of the yield on bonds.

21. See Carl F. Christ, "A Simple Macroeconomic Model with a Government Budget Constraint," Journal of Political Economy, vol. 76 (January-February 1968), pp. 53-67; and William L. Silber, "Fiscal Policy in IS-LM Analysis: A Correction," Journal of Money, Credit, and Banking, vol. 2 (November 1970), pp. 461-72. In a dynamic context, it is necessary to be precise about the passage of time, as well as about problems of stability associated with interest payments on the government debt; see, for example, Blinder and Solow, "Does Fiscal Policy Matter?" As written, 15 strictly applies only to a single time period, where the time unit is identical to that used to define the model's flow variables ( $Y, G$, and so on).

22. Making taxes depend on income would only complicate the algebra without changing any substantive conclusions. 
other words, the investment component of income does not increase the capital stock within the period under analysis. ${ }^{23}$

Behavior in the asset markets, which remains to be represented, is the heart of the matter. In general the public holds all three assets $(M, B, K)$ in its portfolio, so that in principle it is necessary to specify three distinct asset demands. However, because of the balance-sheet constraint emphasized by Brainard and Tobin ${ }^{24}$ - that is, as a consequence of 14 -any one asset demand is a linear combination of the other two and (predetermined) wealth. Hence there are only two independent asset demands, and which two are specified is irrelevant. Even so, the need to specify explicitly the portfolio behavior describing the demands for two assets serves as a useful reminder of the multiplicity of asset markets and the important interrelations among them. By contrast, the standard Keynesian model has only two kinds of assets (money and the collectivity of nonmoney claims, usually called "capital"), so that, after applying the balance-sheet constraint, it is necessary to specify only one asset demand-usually the demand for money. While the resulting model is therefore equivalent to one specifying instead the demand for nonmoney claims, the convention of specifying the demand for money alone has often spawned confusion..$^{25}$

A large literature has investigated the properties of asset demand systems derived from various sets of assumptions about portfolio investors' objectives and their assessments of the risks and rewards associated with

23. Because the capital stock is fixed for the period of this analysis, an appealing generalization would be to follow Tobin by letting the real price of capital $q$ vary; see James Tobin, "A General Equilibrium Approach to Monetary Theory," Journal of Money, Credit, and Banking, vol. 1 (February 1969), pp. 15-29. Replacing $K$ in 14 by $q K$ and adding an equation relating $q$ inversely to the yield on capital, however, would change none of the substantive conclusions derived here. An alternative approach would be to rely on a long-run steady-state growth model as in James Tobin, "Money and Economic Growth," Econometrica, vol. 33 (October 1965), pp. 671-84; in Blinder and Solow, "Does Fiscal Policy Matter?"; or in Martin Feldstein, "Fiscal Policies, Inflation and Capital Formation," working paper 275 (National Bureau of Economic Research, August 1978).

24. William C. Brainard and James Tobin, "Pitfalls in Financial Model Building," American Economic Review, vol. 57 (May 1968), pp. 99-122.

25. For example, the Keynesian speculative demand for money, which depends fundamentally on interest-rate expectations, is simply the negative of the demand for assets subject to capital gains and losses. In the absence of any appeal to expectations, the observed negative interest elasticity of money demand is evidence for the inventory-theoretic interest sensitivity of transactions demand and (contrary to a frequent misinterpretation) has nothing to do with speculative demand. 
holding each specific asset. The common presumption underlying nearly all these treatments is that investors are risk averse, and that at most one asset bears a certain return. For the analysis here, it is useful to think of the return to holding money as fixed (for convenience, at zero) and the respective returns to holding both bonds and capital as uncertain. Especially in the literature of monetary economics, it is customary to express asset demands as both linear in expected returns and first-degree homogeneous in wealth, so that the proportional allocation of the portfolio is invariant to wealth. ${ }^{28}$ For the purposes of this analysis, however, it is more straightforward to preserve the linearity of the model, including the presumed nonnegative dependence of each asset demand on total wealth.

A fully specified system of linear asset demands for the money-bondscapital model is

$$
\left[\begin{array}{l}
M^{D} \\
B^{D} \\
K^{D}
\end{array}\right]=\left[\begin{array}{l}
m_{0} \\
b_{0} \\
k_{0}
\end{array}\right]+\left[\begin{array}{lll}
m_{1} & m_{2} & m_{3} \\
b_{1} & b_{2} & b_{3} \\
k_{1} & k_{2} & k_{3}
\end{array}\right]\left[\begin{array}{l}
r_{M} \\
r_{B} \\
r_{K}
\end{array}\right]+\left[\begin{array}{l}
m_{4} \\
b_{4} \\
k_{4}
\end{array}\right] Y+\left[\begin{array}{l}
m_{5} \\
b_{5} \\
k_{5}
\end{array}\right] W,
$$

where

$$
\begin{aligned}
M^{D}, B^{D}, K^{D} & =\text { the amount of each asset demanded } \\
m_{i}, b_{i}, k_{i} & =\text { fixed coefficients } \\
r_{M} & =\text { the known yield on money } \\
r_{B}, r_{K} & =\text { the respective expected yields on bonds and capital. }
\end{aligned}
$$

From the implications of the balance-sheet constraint,

$$
\begin{aligned}
& m_{i}+b_{i}+k_{i}=0, \quad i=0, \ldots, 4 \\
& m_{5}+b_{5}+k_{5}=1,
\end{aligned}
$$

it is possible to specify the entire asset-demand system in terms of only two fixed coefficients in each column vector. Moreover, if the square

26. Friedman and de Leeuw in particular provided the rationale for the wealth homogeneity constraint. See Milton Friedman, "The Quantity Theory of MoneyA Restatement," in Milton Friedman, ed., Studies in the Quantity Theory of Money (University of Chicago Press, 1956), pp. 3-21; and Frank de Leeuw, "A Model of Financial Behavior," in James S. Duesenberry and others, eds., The Brookings Quarterly Econometric Model of the United States (Rand McNally, 1965), pp. 465530. In "The Effect of Shifting Wealth Ownership on the Term Structure of Interest Rates," working paper 239, rev. (National Bureau of Economic Research, February 1978), I have shown that constant relative risk aversion and joint normally distributed asset-return assessments are sufficient to generate asset-demand functions that are homogeneous in wealth and linear in expected returns, either exactly in a continuous-time model or as an approximation in a discrete-time model. 
matrix indicating the relative asset substitutabilities is symmetric, the further constraints,

$$
b_{1}=m_{2}, \quad k_{1}=m_{3}, \quad k_{2}=b_{3},
$$

also apply. ${ }^{27}$ From 17 and 18 , it is then possible to specify this matrix completely by specifying only three coefficients.

Applying the balance-sheet and symmetry constraints in the way that will prove most convenient (because it is analytically irrelevant which coefficients they eliminate) renders the asset-demand system 16 as

$$
\begin{aligned}
{\left[\begin{array}{l}
M^{D} \\
B^{D} \\
K^{D}
\end{array}\right]=\left[\begin{array}{c}
m_{0} \\
b_{0} \\
-m_{0}-b_{0}
\end{array}\right]+} & {\left[\begin{array}{ccc}
-m_{2}-m_{3} & m_{2} & m_{8} \\
m_{2} & -m_{2}-b_{3} & b_{3} \\
m_{3} & b_{3} & -m_{3}-b_{3}
\end{array}\right]\left[\begin{array}{l}
r_{M} \\
r_{B} \\
r_{K}
\end{array}\right] } \\
& +\left[\begin{array}{c}
m_{4} \\
b_{4} \\
-m_{4}-b_{4}
\end{array}\right] Y+\left[\begin{array}{c}
m_{5} \\
b_{5} \\
1-m_{5}-b_{5}
\end{array}\right] W .
\end{aligned}
$$

Within the matrix, the purpose underlying the arbitrary selection is to retain explicitly the three off-diagonal coefficients indicating the relative asset substitutabilities. On the common assumption that the three assets are gross substitutes, these three coefficients are each negative, and from 17 the on-diagonal own-yield coefficients are then positive as expected.28 To complete the specification of behavior in the asset markets, it is necessary only to add the market-clearing equilibrium condition extending 5 as

$$
\left[\begin{array}{l}
M^{D} \\
B^{D} \\
K^{D}
\end{array}\right]=\left[\begin{array}{l}
M \\
B \\
K
\end{array}\right] .
$$

27. Despite the frequent immediate resort to symmetry constraints by researchers who apparently assume that the properties of consumer demand theory necessarily carry over to portfolio theory, symmetry in derived asset-demand systems implies strong restrictions on the underlying utility function. For a careful treatment of this question, see V. Vance Roley, "A Structural Model of the U.S. Government Securities Market" (Ph.D. dissertation, Harvard University, 1977).

28. The elements of this matrix are functions of the variance-covariance matrix of the asset-return assessments. Blanchard and Plantes have shown that gross substitution requires a positive covariance between each pair of uncertain returns; see Olivier J. Blanchard and Mary Kay Plantes, "A Note on Gross Substitutability of Financial Assets," Econometrica, vol. 45 (April 1977), pp. 769-71. 
Because the model now includes two asset yields, rather than only one as in the simpler model employed in the previous section, it is also necessary to be more specific about "the interest rate" in the $I S$ curve. The role of the yield variable in 13, which follows from the underlying investment function 2 , is to represent the effect of the expected return that is required to induce spending for plants, equipment, houses, or other long-lived physical assets; and the negative sign of this effect follows from the presumption that, the lower is this required return, the more physical assets are able to provide it. Hence it is clear that the interest rate in the $I S$ curve is $r_{K}$, the expected yield on real capital. ${ }^{29}$

When $G, T, M, K, r_{M}$, and the initial stock of bonds $B_{0}$ are treated as exogenous, the eight-equation model consisting of $13,14,15$, any two components of 19 , and all three components of 20 suffice to determine $Y, W, B, r_{B}, r_{K}, M^{D}, B^{D}$, and $K^{D}$. It is more useful, however, to solve the model in a three-equation form determining $Y, r_{B}$, and $r_{K}$, analogous to the two-equation $I S-L M$ model. With $r_{M}$ fixed at zero for convenience, the model is

$$
\begin{gathered}
Y=y_{0}+y_{1} G+\left(1-y_{1}\right) T+y_{2} r_{K}+y_{3}(M+K+B) \\
M=m_{0}+m_{2} r_{B}+m_{3} r_{K}+m_{4} Y+m_{5}(M+K+B) \\
B=b_{0}-\left(m_{2}+b_{3}\right) r_{B}+b_{3} r_{K}+b_{4} Y+b_{5}(M+K+B) .
\end{gathered}
$$

The diagram below plots 21 and 22 in $\left(r_{K}, Y\right)$ space as conditional $I S$ and $L M$ curves, making explicit that the $I S$ curve is conditional on the values of $G, M, K, B$, and $T$, while the $L M$ curve is conditional on the values of $M, K, B$, and $r_{B} \cdot{ }^{30}$ The dependence of the positions of both curves on the quantities of the three assets that are given in a balanced budget situation is straightforward, but the dependence of the $L M$ curve on $r_{B}$ is more interesting. If the model is normalized to solve 21 and 22 for $Y$ and $r_{K}$, as implied in the diagram, then 23 determines $r_{B}$-which in turn affects the positions and hence the intersection of 21 and 22 in the

29. Rather than relate $Y$ negatively to $r_{K}, 13$ could relate $Y$ positively to $q$ (with $q$ related inversely to $r_{K}$ ); see note 23. Alternatively, in a more complicated model including both government bonds and private bonds, 13 could relate $Y$ negatively to a composite "cost of capital" consisting of a weighted combination of $r_{K}$ and the interest rate on private borrowing.

30. Allowing for the dependence of $B$ on $r_{B}$ would further complicate the sense in which the $L M$ curve is conditional on $r_{B}$, and would also render the $I S$ curve conditional on $r_{B}$. 


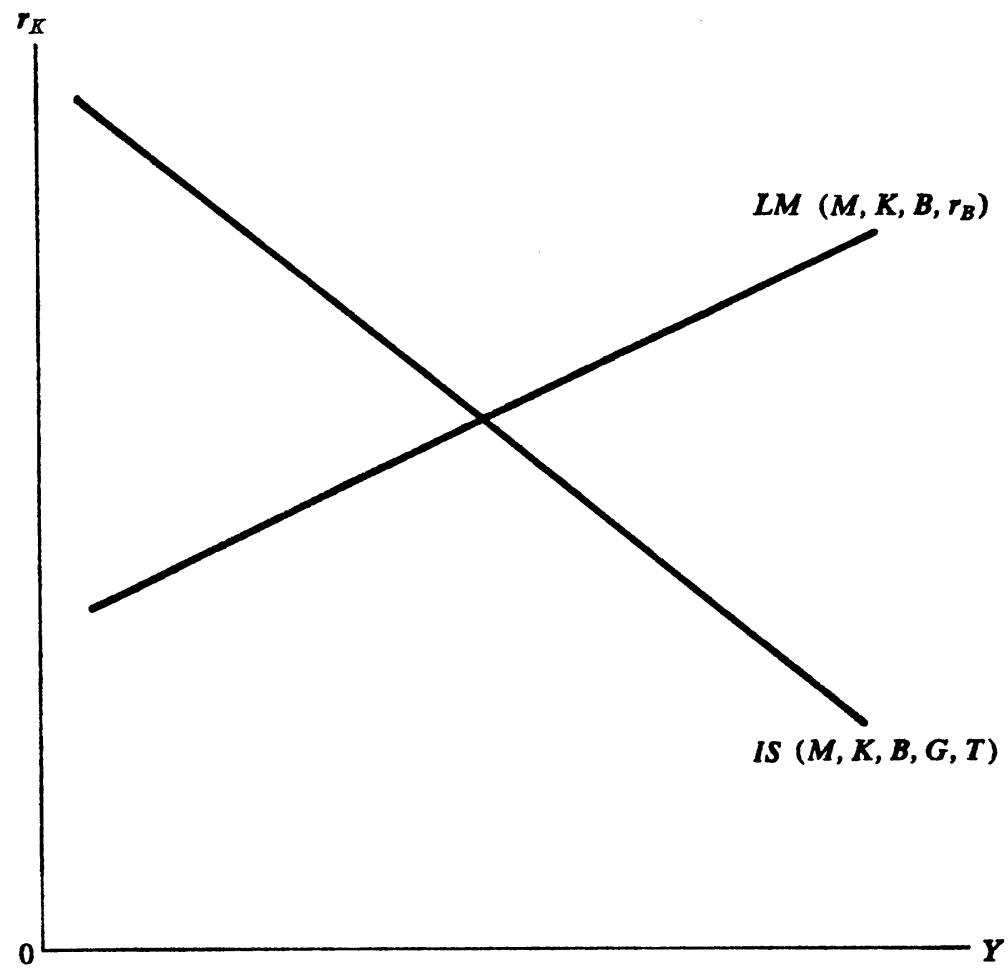

$\left(r_{K}, Y\right)$ space. But both $r_{K}$ and $Y$ are also arguments of 23. Hence $r_{K}, Y$, and $r_{B}$ are jointly determined in a fully simultaneous way, and any representation in only two dimensions is misleading without attention to the omitted codetermined variable.

It is now possible to reexamine the consequences of fiscal policy, using the condensed model of 21 through 23 together with a statement of how any associated deficit is financed. The partial-equilibrium in the goods market differs only slightly from that in the model without wealth effects reviewed in the previous section. From 21 and the government financing constraint, $d G=d B+d M$, the effect of raising government spending above the balanced budget level is simply

$$
\frac{\partial Y}{\partial G}=y_{1}+y_{3}
$$

The $y_{1}$ is identical to $1 /\left(1-c_{1}\right)$ in 8 , and thus the goods-market wealth effect of financing the deficit reinforces the usual multiplier effect of fiscal 
policy. (Hence the rightward shift from $I S_{0}$, conditional on $G_{0}$, to $I S_{1}$, conditional on $G_{1}>G_{0}$, as shown in the diagram on page 619 , exceeds the analogous rightward $I S$ shift in the first diagram of this article.)

The asset-market equations 22 and 23 reflect two effects of deficits. Transactions crowding out is familiar from the previous section and should require little further discussion. Given $m_{k}>0$, the additional income from the goods-market effect increases the transactions demand for money. If $M$ remains unchanged, either or both $r_{B}$ and $r_{K}$ must rise (recall that $m_{2}, m_{3}<0$ ) to clear the money market. If both $M$ and $B$ were to remain fixed, in violation of the government financing constraint, solving the model shows that $r_{B}$ and $r_{K}$ would both rise. Given $y_{2}<0$, the increase in $r_{K}$ would in turn offset some part of the income effect in the goods market. As long as the assets are all gross substitutes, the multiasset model leaves unchanged the conclusion that transactions crowding out is unambiguously in the "out" direction.

What about portfolio crowding out? Under bond financing of the deficit, $M$ again remains unchanged but total wealth, $M+B+K$, increases. Given $m_{5}>0$, an assumption examined empirically below, in the money market the wealth effect reinforces the transactions effect, making a larger net excess demand for money. Hence an even greater rise in either or both $r_{B}$ and $r_{K}$ is necessary to clear the money market.

In the presence of wealth effects, however, it is no longer so simple to determine whether what clears the money market is a rise in both $r_{B}$ and $r_{K}$ or in only one of them. The entire increase in wealth resulting from financing the deficit consists of an increase in the outstanding stock of bonds. However, given $0<b_{5}<1$-that is, assuming that people do not want to hold all their increased wealth in the form of increased bonds-a net excess supply of bonds emerges in the absence of yield changes. Moreover, just as the balance-sheet constraint implies $b_{5}<1$ if $m_{5}>0$, it is plausible to assume that the counterpart to $m_{4}>0$ is $b_{4}<0$, so that the transactions effect makes this net excess supply of bonds even greater. Since the demand for bonds depends positively on $r_{B}$ and negatively on $r_{K}$, the yield movements that eliminate this net excess supply must be either an increase in $r_{B}$ (which also helps eliminate the net excess demand for money), or a decrease in $r_{K}$ (which compounds the net excess demand for money), or both.

Because of the linear dependence of the three asset-demand equations, examining the capital market per se can provide no further information, 
but it does serve as a useful aid to intuition. Given $k_{5}=1-m_{5}-b_{5}>0$, the increase in total wealth raises the demand for capital, but in the short run $K$ remains unchanged. On the assumption that $k_{4}<0$, however, the transactions effect reduces the demand for capital. If the portfolio effect outweighs the transactions effect, ${ }^{31}$ the yield movements necessary to eliminate the net excess demand for capital must again be either an increase in $r_{B}$, a decrease in $r_{K}$, or both.

Because an increase in $r_{B}$ not only helps eliminate net excess demand in the money market (and the capital market) but also helps reduce net excess supply in the bond market, $r_{B}$ unambiguously rises as the result of bond-financed government deficit spending. By contrast, while an increase in $r_{K}$, which would reduce real investment, helps clear the money market, a decrease in $r_{K}$, which would stimulate real investment, helps clear the bond market (and the capital market). Hence it is impossible to tell a priori whether $r_{K}$ rises or falls. Because the effect of interest rates in the goods market depends on $r_{K}$, it is impossible to tell a priori whether the portfolio effect (or the sum of the portfolio effect plus the transactions effect) will offset or reinforce the income effect of fiscal policy.

Solving 22 and 23 for the partial-equilibrium "asset-markets-only" effect of $d B=d G$, with $Y$ fixed, indicates whether the portfolio effect per se is one of crowding out or crowding in. The relevant partial derivatives-solved from 22 and 23, and hence partial only because they do not allow for 21-are

$$
\begin{gathered}
\frac{\partial r_{B}}{\partial G}=-\frac{b_{3} m_{5}+m_{3}\left(1-b_{5}\right)}{\Delta} \\
\frac{\partial r_{K}}{\partial G}=\frac{m_{2}\left(1-b_{5}\right)-m_{2} m_{5}-b_{3} m_{5}}{\Delta},
\end{gathered}
$$

where the determinant $\Delta$ is the sum of cross-products of the three key substitution coefficients,

$$
\Delta=m_{2} m_{3}+m_{2} b_{3}+m_{3} b_{3} .
$$

If all three assets are substitutes $\left(m_{2}, m_{3}, b_{3}<0\right), \Delta$ is strictly positive. Consequently, as long as people do not want to hold all the new wealth in bonds $\left(b_{5}<1\right)$, equation 25 confirms that $r_{B}$ unambiguously rises with

31. The portfolio effect is the more likely to outweigh the transactions effect as more than the single time period elapses because the stock of bonds continues to grow if the deficit continues. 
a bond-financed increase in $G$. By contrast, as long as people also want to hold at least some of the new wealth in money $\left(m_{5}>0\right)$, the numerator of 26 consists of one negative term minus two other negative terms, so that whether $r_{K}$ rises or falls with a bond-financed increase in $G$-that is, whether the portfolio effect constitutes crowding out or crowding independs on the magnitudes of the two key substitution coefficients $m_{2}$ and $b_{3}$.

Hence the question of whether the portfolio effect of bond-financed deficit spending crowds out or crowds in private investment reduces to the long-debated issue of whether bonds are closer portfolio substitutes for money or for capital..$^{32}$ Given the symmetry assumption of 18 , it is convenient to summarize the relevant asset substitutability properties in terms of a relative substitutability index defined as

$$
\sigma \equiv \frac{m_{2}}{b_{8}}\left(=\frac{b_{1}}{k_{2}}\right)
$$

This index is the ratio of the substitutability of bonds for money (and vice versa) to the substitutability of bonds for capital (and vice versa). Given $m_{2}, b_{3}<0, \sigma$ is strictly positive. If bonds are close substitutes for money but not for capital, $m_{2}$ is large and $b_{3}$ small, so that $\sigma$ is large. If bonds are close substitutes for capital but not for money, $m_{2}$ is small and $b_{3}$ large, so that $\sigma$ is small. In principle the index $\sigma$ can describe any position on the relative substitutability scale between $\sigma=0$ (bonds and capital are perfect substitutes) and $\sigma=\infty$ (bonds and money are perfect substitutes).

From 26, then, the sign of the portfolio effect of bond-financed deficit spending hinges on the relative substitutability condition

$$
\frac{\partial r_{K}}{\partial G} \gtrless 0 \quad \text { as } \quad \sigma \lessgtr \sigma^{*},
$$

where the critical value $\sigma^{*}$ is simply ${ }^{38}$

$$
\sigma^{*}=\frac{m_{5}}{1-b_{5}-m_{5}}\left(=\frac{m_{5}}{k_{5}}\right) \text {. }
$$

32. See, for example, Tobin, "Money, Capital, and Other Stores of Value"; Tobin, "An Essay on Principles of Debt Management"; Tobin, "A General Equilibrium Approach"; and Karl Brunner and Allan H. Meltzer, "Money, Debt, and Economic Activity," Journal of Political Economy, vol. 80 (September-October 1972), pp. 951-77.

33. It is interesting to note that this result is independent of $m_{3}\left(=k_{1}\right)$, the elasticity of substitution between money and capital. 
Hence there is portfolio crowding out when the value of the relative substitutability index - that is, the interest rate coefficient ratio-is smaller than the corresponding wealth coefficient ratio, but portfolio crowding in when the index is greater than the wealth coefficient ratio.

The diagram below summarizes this analysis graphically by plotting in $\left(r_{K}, Y\right)$ space several conditional $L M$ curves representing the money market equilibrium of 22. First, $L M_{0}$ indicates the locus of $\left(r_{K}, Y\right)$ pairs that will clear the money market given the values of the initial balancedbudget equilibrium with $M_{0}, K_{0}, B_{0}, r_{B_{0}}$. Because the bond financing of deficit spending changes $B$ according to $d B=d G$, as well as $r_{B}$ according to 22 , the $L M$ curve in general shifts as a consequence of the fiscal policy action, with a new locus $L M$, associated with $B_{1}$ and $r_{B_{1}}$. The increase in $B$ tends to shift $L M_{1}$ leftward (that is, to raise the market-clearing value of $r_{K}$

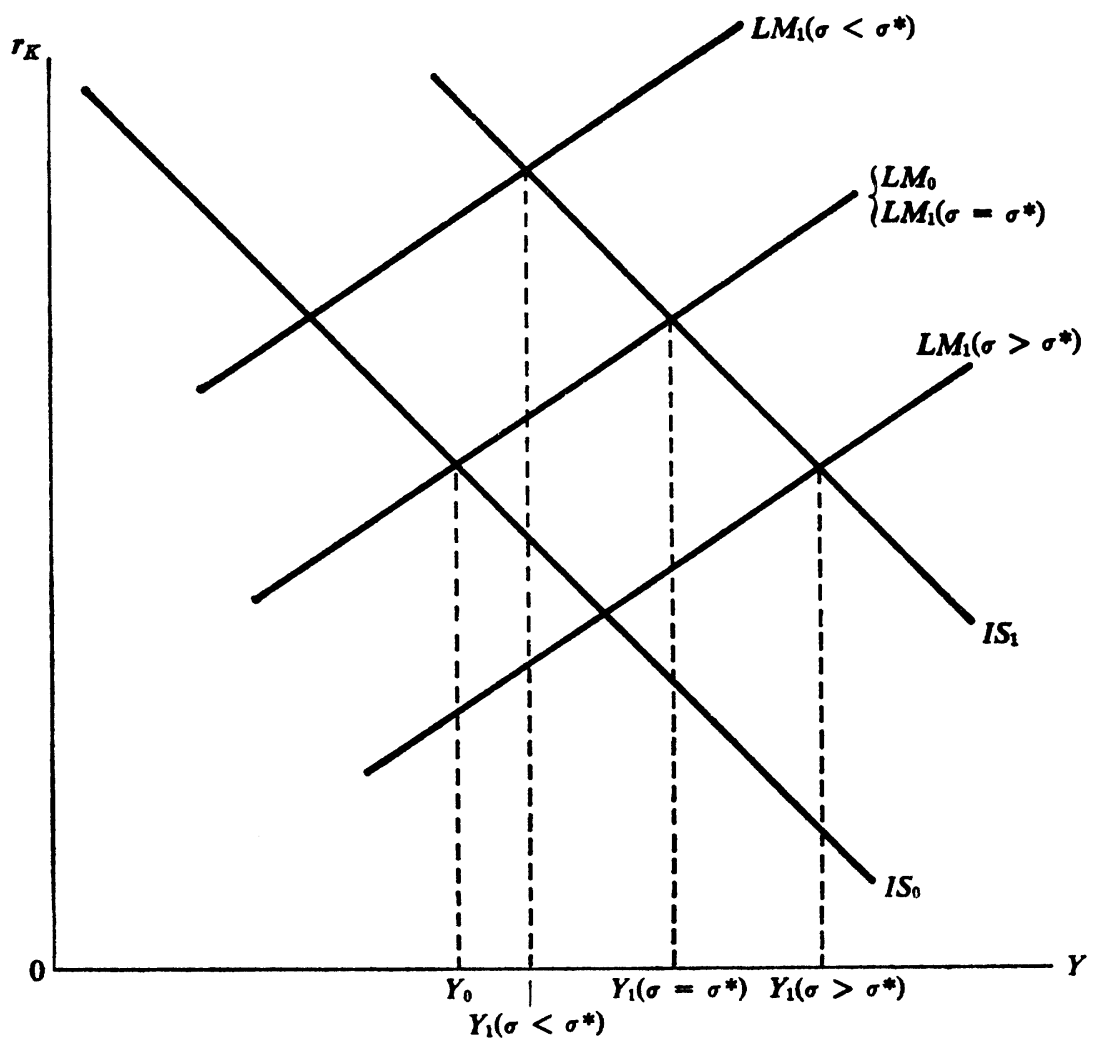


for given $Y$ ), while the rise in $r_{B}$ tends to shift $L M_{1}$ rightward. Which effect predominates depends on the relative substitutability condition of 29.

If $\sigma=\sigma^{*}$, the two components of the portfolio effect exactly offset one another, so that the conditional $L M$ curve shifts neither rightward nor leftward, and the rightward shift of the conditional $I S$ curve (from $I S_{0}$ to $I S_{1}$ ), together with traditional Hicks' transactions crowding out, is the entire story of bond-financed deficits.

If $\sigma<\sigma^{*}$-that is, if bonds are more substitutable for capital and less substitutable for money than $\sigma^{*}$ - the conditional $L M$ curve shifts leftward, and portfolio crowding out joins transactions crowding out. In contrast to transactions crowding out, however, which can offset only a part of the income effect of fiscal policy, portfolio crowding out can result in $Y_{1}<Y_{0}$ if the conditional $L M$ curve shifts leftward far enough. (The diagram shows the $Y_{1}$ value conditional on $\sigma<\sigma^{*}$ as greater than $Y_{0}$, but the opposite could also be true a priori.)

Finally, if $\sigma>\sigma^{*}$, the conditional $L M$ curve shifts rightward, and portfolio crowding in reinforces the income effect of fiscal policy. In this case the resulting $Y_{1}$ is not merely greater than $Y_{0}$ but greater than the value of $Y_{1}$ for $\sigma=\sigma^{*}$ corresponding to the traditional $I S-L M$ analysis with transactions crowding out only.

\section{SOME SPECIAL CASES}

Because the previous literature on portfolio crowding out has typically derived rather different results from those presented above, it is important to show how alternative results emerge as special cases within the model developed here. Two principal issues pertain to the wealth coefficients and the interest rate coefficients of the asset-demand equations of 16 . In both cases the relative substitutability condition of 29 serves as a useful tool of analysis.

First, many economists have argued that the only motive for holding money balances is to facilitate transactions, so that the role of money as a store of value generates no money holding for portfolio purposes. Ando and Shell have formalized the argument for excluding wealth from the money demand function, and Goldfeld and others have provided empirical evidence on this question. ${ }^{84}$ If money demand is independent of

34. Albert Ando and Karl Shell, "Appendix: Demand for Money in a General Portfolio Model in the Presence of an Asset that Dominates Money," in Gary 
wealth, then portfolio crowding out cannot occur, and the only possibilities are portfolio crowding in or an unshifting conditional $L M$ curve. If $m_{5}=0$ (and $0<b_{5}, k_{5}<1$ ), the critical value of the relative substitutability index is $\sigma^{*}=0$, and $\sigma<\sigma^{*}$ is impossible. If bonds are even slightly substitutable for money $\left(m_{2} \neq 0\right)$, then $\sigma>\sigma^{*}$, and there is automatically portfolio crowding in. Alternatively, if bonds and money are not substitutes $\left(m_{2}=0\right)$, then $\sigma=0$ also, and the conditional $L M$ curve does not shift.

Second, it is an unfortunate legacy of Keynes' General Theory that many economists continue to work with a two-asset model in which all nonmoney claims are by assumption perfect substitutes. If bonds and capital are perfect substitutes, portfolio crowding in cannot occur, and the only possibilities are portfolio crowding out or an unshifting conditional $L M$ curve. In the limit as $b_{3}$ becomes large (in absolute value), $\sigma=0$ regardless of $m_{2}$ (unless $m_{2}$ is also infinite, indicating a one-asset model), and $\sigma>\sigma^{*}$ is impossible. If money demand depends on wealth $\left(m_{5} \neq 0\right)$, then $\sigma<\sigma^{*}$, and there is automatically portfolio crowding out. Alternatively, if $m_{5}=0$, then $\sigma^{*}=0$ also, and the conditional $L M$ curve does not shift.

The well-known analysis due to Blinder and Solow is an example of this second special case. ${ }^{35}$ By assuming that bonds and capital are perfect substitutes $(\sigma=0)$, Blinder and Solow arbitrarily preclude portfolio crowding in for the stable form of their model. Hence their analysis of "bond finance"- that is, issuing government bonds that are perfect substitutes for capital-refers to one extreme case. One also could describe "money finance," for which the $L M$ curve unquestionably shifts rightward, as the polar case of issuing government bonds that are perfect substitutes for money (that is, $\sigma=\infty$ ) -but there seems little point in doing so. Similarly, it is misleading to think of the opposite polar case, which Blinder and Solow call "bond finance," as a general description of bond financing of government deficits.

The potential validity of these special assumptions about both the wealth responses and the interest rate responses of the portfolio demand system is essentially an empirical issue, and thus it is appropriate to ex-

Fromm and Lawrence R. Klein, eds., The Brookings Model: Perspective and Recent Developments (Amsterdam: North-Holland, 1975; distributor, American Elsevier), pp. 560-63; Goldfeld, "The Demand for Money Revisited."

35. Blinder and Solow, "Does Fiscal Policy Matter?" 
amine the available evidence. In the following section I introduce evidence on the wealth elasticity of the demand for money. Consideration of the asset substitutability question follows a further generalization of the model.

\section{MONEY DEMAND AND WEALTH}

Whether the demand for money depends on income, wealth, or both is an old issue in monetary economics. Fisher's transactions version of the quantity equation emphasized the role of money as a means of payment, while the Cambridge cash-balance version due to Lavington and Pigou relied on money as a store of value. ${ }^{36} \mathrm{Keynes}$ accepted both in distinguishing the transactions and speculative components of money demand. ${ }^{87}$ Despite some allegiance to the Fisherian quantity theory, monetarists have typically followed Milton Friedman in accepting both rationales for holding money, although their empirical work has usually favored income over wealth. ${ }^{88}$ Although the question of whether money demand depends on income or wealth is often stated in terms of money as a means of payment versus money as a store of value, in fact the issue is not nearly so clear-cut. For example, even in the context of a pure transactions model, money demand will still depend on wealth if wealth levels affect attitudes toward convenience, or if money is used in financial transactions.

In his review of the evidence on the demand for money five years ago, Goldfeld explicitly compared the results of using income and of using wealth (defined as total household net worth) in the money-demand function. In brief, using data for 1952:2 through 1972:4, he found that the wealth elasticity differed significantly from zero only when income was excluded from the equation, while the income elasticity differed significantly from zero regardless of whether wealth was included or ex-

36. Irving Fisher, The Purchasing Power of Money: Its Determination and Relation to Credit, Interest and Crises (Macmillan, 1911); F. Lavington, The English Capital Market (London: Methuen, 1921); Pigou, "The Value of Money." Marshall had also acknowledged the dependence of money demand on wealth; see Alfred Marshall, Money, Credit and Commerce (London: Macmillan, 1923).

37. Keynes, General Theory.

38. Milton Friedman, "The Demand for Money: Some Theoretical and Empirical Results," Journal of Political Economy, vol. 67 (August 1959), pp. 327-51. An important exception is Meltzer's work; see, for example, Allan H. Meltzer, "The Demand for Money: The Evidence from the Time Series," Journal of Political Economy, vol. 71 (June 1963), pp. 219-46. 
cluded. ${ }^{39}$ In his subsequent investigation into the "mystery of the missing money"40 - that is, the consistent large overprediction for the moneydemand equation after 1973 - he used 1952:2 to 1973:4 data and found that, with both income and wealth included in the equation, the $t$-statistics for the respective elasticities were 3.0 and 2.3. Extrapolation exercises, however, showed that including wealth did not clear up the overprediction mystery. According to Goldfeld's evidence, therefore, there is little basis for rejecting the special case of Ando and Shell in which, because of a zero wealth elasticity of money demand, crowding out cannot occur.

Table 4 presents the results of estimating a money-demand function comparable to that of Goldfeld; it includes income and wealth alternately and then includes both, using first Goldfeld's original sample (1952:2 to 1972:4) and then a sample for 1952:2 to $1977: 4 .^{41}$ The table reports results for equations based on a real adjustment and then a nominal adjustment, as in Goldfeld's earlier and later work, respectively.

The results shown in the table for 1952:2 to $1972: 4$ essentially replicate Goldfeld's earlier findings. Under either the real or the nominal adjustment, the standard error is minimized in the equation that includes income but not wealth. Adding wealth neither raises nor lowers the standard error. The wealth elasticity differs significantly from zero only if income is excluded. In equation 2 with a real adjustment that includes wealth but not income, the implied speed of adjustment is implausibly slow. In equation 5, with a nominal adjustment that includes wealth but not income, the implied speed of adjustment is negative.

The next results, for 1952:2 through 1977:4, differ sharply from those for 1952:2 to 1972:4 in several ways. With both the real and the nominal adjustment, the standard error is minimized in the equation including both income and wealth, and the elasticities with respect to both variables differ significantly from zero. The equations with the nominal adjustment fit the data uniformly better, but always at the expense of

39. Goldfeld, "The Demand for Money Revisited." Goldfeld did find a significant elasticity with respect to the change in wealth, but it is difficult to interpret this result, and he did not emphasize it.

40. Goldfeld, "Missing Money."

41. In the results shown in the table, the wealth variable is household financial asset holdings. The results do not change much if any of three other definitions of wealth is used instead: household financial net worth, household total asset holdings, or household total net worth; these alternate results are available from the author on request. 


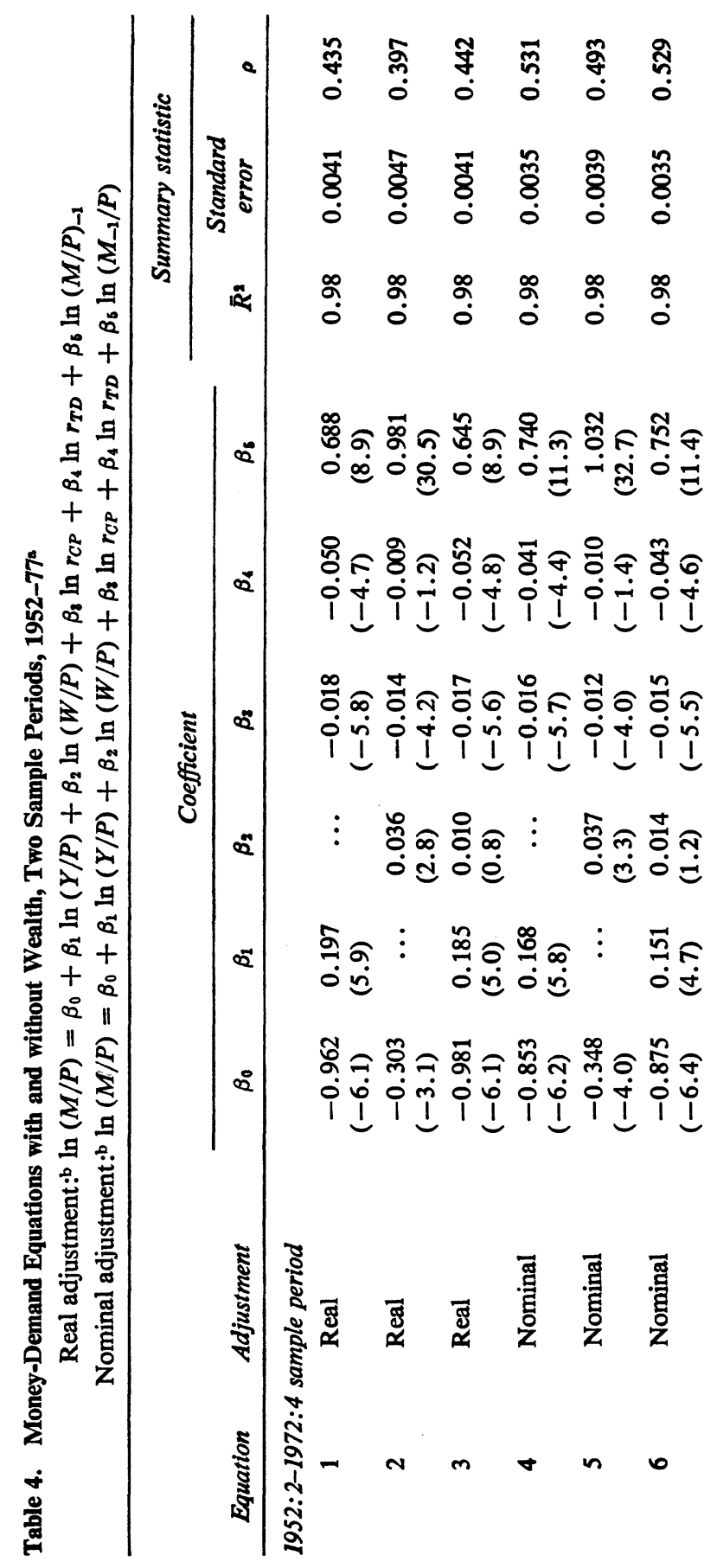




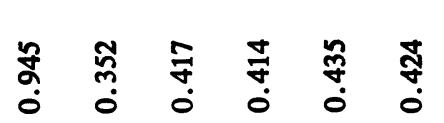

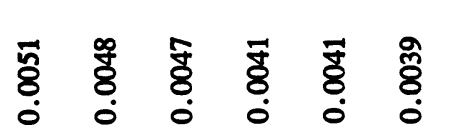

ஸீ

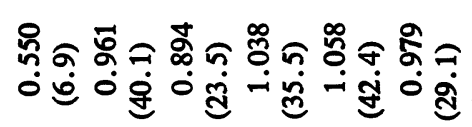

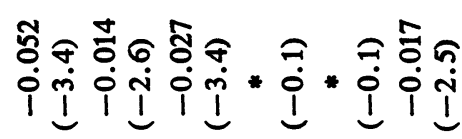

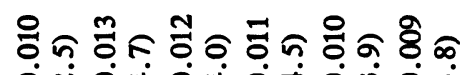

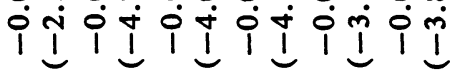

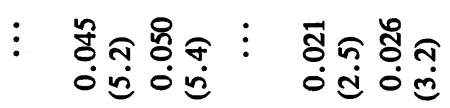

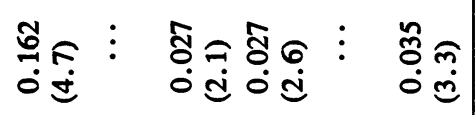

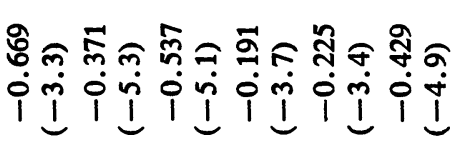

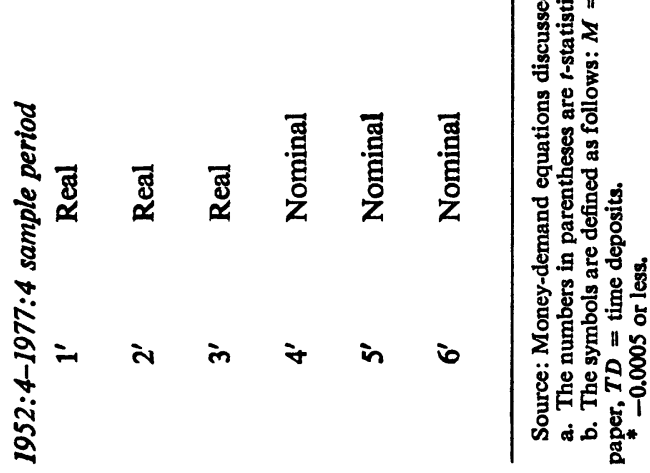


Table 5. F-Statistics for Stability Tests of Money-Demand Equations

\begin{tabular}{cllc}
\hline Equation & Variable & Adjustment & F-statistic \\
\hline 1 & Income & Real & 6.25 \\
& & & $(6,91)$ \\
4 & Income & Nominal & 6.14 \\
& & & $(6,91)$ \\
2 & Wealth & Real & 1.68 \\
& & & $(6,91)$ \\
5 & Wealth & Nominal & 1.89 \\
& & & $(6,91)$ \\
3 & Income & Real & 4.82 \\
& Wealth & & $(7,89)$ \\
6 & Income & Nominal & 3.69 \\
& Wealth & & $(7,89)$ \\
\hline
\end{tabular}

Source: Derived from corresponding equations in table 4.

a. The numbers in parentheses indicate the degrees of freedom. The critical values of $F$ for $(6,91)$ are: 95-percent level, 2.20; 99-percent level, 3.02. The critical values of $F$ for $(7,89)$ are: 95 -percent level, 2.11 ; 99-percent level, 2.85 .

negative or implausibly slow adjustment speeds. The rapid adjustment and large $\rho$ value of the original Goldfeld equation for 1952:4 to 1977:4 (see $1^{\prime}$ ), indicates a further severe problem.

The results for 1952:2 through 1977:4, suggesting the dependence of money demand on wealth, therefore call into question the most familiar argument against the possibility of portfolio crowding out. Because the contrast between these results and those for the earlier sample suggests some change in the underlying behavior, however, it is interesting to test for the presence of a structural shift at the end of 1972 . The $F$-statistics presented in table 5 for Chow tests of the hypothesis of no structural shift provide some further support for the dependence of money demand on wealth, although the full set of results is somewhat puzzling. Under both the real and nominal adjustment the results warrant rejecting with 99 percent confidence the stability of the equation relating money demand to income; but they do not warrant rejecting the stability of the equation relating money demand to wealth, even at the weaker 95 percent confidence level. What is perplexing, however, is that under both the real and nominal adjustment the results warrant rejecting with 99 percent confidence the stability of the equation relating money demand to both income and wealth. The question here is whether to include wealth, and not 
whether to exclude income. Hence the contrast between these results must remain a topic for further research. ${ }^{42}$

These limited empirical results are far from conclusive, and investigating the money-demand function per se is not the objective of this article. Nevertheless, the results shown in tables 4 and 5 provide little empirical support for the assumption of zero wealth elasticity that would preclude portfolio crowding out.

\section{A DIGRESSION ON THE MYSTERY OF THE}

\section{MISSING MONBY}

Equations relating money demand to income show a significant break after 1972, while those related to wealth do not. This finding suggests that the difference between the two specifications may have something to do with the post-1972 overprediction mystery, an episode that has attracted much attention because of its critical implications for monetary policy. It is worthwhile to examine whether the distinction between income and wealth does in fact provide any light here.

Table 6 summarizes the results of simulating, over 1973:1 to 1977:4, various money-demand functions estimated for the sample from 1952:2 to $1972: 4$. In each case the simulation is dynamic-after 1973:1, the internally generated value is used for the lagged money stock.

The first six simulated equations are those also considered in table 5 and shown in full in table 4 . The equations relating money demand either to income alone or to both income and wealth show the familiar large overprediction that continues to worsen throughout the simulation period. The equation relating money demand to wealth alone under the real adjustment (2) also overpredicts, but with far smaller errors that do not tend to increase toward the end of the simulation period. However, equation 5, relating money demand to wealth under the nominal adjustment, consistently underpredicts throughout the simulation period (because of the negative estimated adjustment speed as shown in table 4) and has the largest absolute mean and root-mean-square errors of the six. Hence relat-

42. Two recent papers have usefully set forth the case for a shift in the relationship between money demand and income because of changes in banking technology. See Gillian Garcia and Simon Pak, "Some Clues in the Case of the Missing Money" (University of California at Berkeley, Department of Economics, February 1978); and Richard D. Porter and Eileen Mauskopf, "Cash Management and the Recent Shift in the Demand for Demand Deposits" (Federal Reserve Board, November 1978). 
Table 6. Dynamic Simulation Results for Money-Demand Equations, 1952:2-1972:4 Sample Period

Billions of dollars

\begin{tabular}{|c|c|c|c|c|c|}
\hline \multirow[b]{2}{*}{ Equation } & \multirow[b]{2}{*}{ Variable } & \multirow[b]{2}{*}{ Adjustment } & \multicolumn{2}{|c|}{ 1973:1-1977:4 errors } & \multirow[b]{2}{*}{ 1977:4 error } \\
\hline & & & Mean & $\begin{array}{l}\text { Root-mean- } \\
\text { square }\end{array}$ & \\
\hline 1 & Income & Real & 21.4 & 26.5 & 46.2 \\
\hline 4 & Income & Nominal & 18.8 & 25.4 & 48.0 \\
\hline 2 & Wealth & Real & 4.5 & 5.6 & 5.0 \\
\hline 5 & Wealth & Nominal & -22.9 & 27.8 & -52.3 \\
\hline 3 & $\begin{array}{l}\text { Income } \\
\text { Wealth }\end{array}$ & Real & 19.2 & 24.2 & 42.3 \\
\hline 6 & $\begin{array}{l}\text { Income } \\
\text { Wealth }\end{array}$ & Nominal & 14.9 & 21.3 & 41.2 \\
\hline Hamburger's equation & $\cdots$ & $\cdots$ & 8.0 & 9.6 & 16.1 \\
\hline $\begin{array}{l}\text { Hamburger's equation } \\
\text { with wealth }\end{array}$ & $\cdots$ & $\cdots$ & -0.4 & 1.9 & -0.8 \\
\hline
\end{tabular}

Sources: Derived from corresponding equations in table 4, from the money-demand equation in Hamburger, "Behavior of the Money Stock," and from a variant of the Hamburger equation discussed in the text.

a. The money-stock variable for the first six equations is based on Goldfeld's three-month average centered on the middle of the quarter; in the last two equations, this variable is based on Hamburger's two-month average centered on the end of the quarter.

ing money demand only to wealth does achieve a marked improvement, but this is restricted to the real adjustment.

This discussion of the mystery of the missing money also requires consideration of Hamburger's proposed solution. ${ }^{43}$ His money-demand equation, estimated for 1955:2 to 1972:4, demonstrably outperforms equations like Goldfeld's in post-1972 simulations. For purposes of the current discussion, the most interesting property of the Hamburger equation is its inclusion of the dividend-price ratio of common stocks, intended to capture the elasticity of substitution between money and equity securities. The estimated elasticity is significantly less than zero ( $t$-statistic, -2.5 ).

It is also possible to give an entirely different interpretation to the role played by the dividend-price ratio in Hamburger's money-demand equation. Because common stock dividends are a fairly stable trendlike series over time, most variation of the dividend-price ratio stems from the variation in stock prices. Moreover, the variation of stock prices in turn accounts for most of the measured variation of household wealth because

43. Hamburger, "Behavior of the Money Stock." 
equities are both the largest and the most volatilely valued component of household assets. To the extent that dividends rise roughly like a price index over time, therefore, the time-series behavior of the dividend-price ratio serves as a close proxy for the time-series behavior of (the reciprocal of) the real value of household wealth. In addition, Hamburger's equation includes no explicit wealth variable, despite his strong appeal to the generalized portfolio concept that money is a substitute for a broad range of assets.

What happens if household wealth replaces the dividend-price ratio in Hamburger's money-demand equation? The answer is that the estimated results differ negligibly but that, as the equations reported in table 6 show, the wealth form of the equation substantially outperforms Hamburger's own dividend-price form in post-1972 simulations. In fact, the Hamburger equation with wealth substituted for the dividend-price ratio tracks the postsample data astonishingly well, with only a slight tendency to underpredict on average. A plausible conclusion is that Hamburger's proposed solution for the mystery of the missing money is simply a disguised story about the role of wealth in the money-demand function, and that the solution works better without the disguise.

\section{SUMMARY}

Several theoretical and empirical conclusions emerge from the investigation of portfolio crowding out and crowding in.

In a general model including money, bonds, and capital, there is no justification for presuming a priori whether the portfolio effect associated with bond-financed government deficits offsets or reinforces the familiar income effect of fiscal policy.

Whether this portfolio effect is positive or negative depends on a crucial but simple relative substitutability condition: portfolio crowding out (or crowding in) results when the ratio of the substitution coefficient between bonds and money to the substitution coefficient between bonds and capital is smaller (greater) than the ratio of the respective wealth coefficients of the demands for money and capital. If the two ratios are precisely equal, there is no portfolio effect, and the traditional $I S-L M$ analysis is adequate to describe bond-financed government deficits.

If portfolio crowding out does occur, in general it can (unlike transactions crowding out) offset more than all of the standard income effect of fiscal policy. 
Special cases occur in the general model: if the wealth elasticity of money demand is zero, portfolio crowding out cannot occur. If bonds and capital are perfect substitutes, portfolio crowding in cannot occur.

The most recent empirical evidence does not support the contention that the wealth elasticity of money demand is zero. Instead, the role of wealth in the money-demand function provides potential clues to the troublesome post-1972 overprediction problem of conventional moneydemand equations.

\section{Portfolio Substitutabilities and the Role of Debt-Management Policy}

The question of what forms of holding wealth are close or distant substitutes for others has long intrigued monetary economists. As the previous section has shown, this issue lies at the core of the analysis of fiscal policy involving bond-financed deficits.

Two distinct approaches facilitate analyzing the substitutability for other assets of government nonmoney debt claims. The positive approach is to accept as given the terms of these claims and then to investigate the properties of the public's demands for them, bringing to bear whatever empirical evidence is available. Alternatively, because the government is free to set the terms on such claims, just as the public is free to decide at what price (or whether at all) it will accept them, the normative approach is to treat the intended economic effect as given and to ask what terms on government debt claims will best achieve it. Pursuing the normative approach leads directly to the consideration of debt-management policy, a topic that economists have allowed to lie fallow for more than a decade.

\section{COMPOSITION OF THE FEDERAL DEBT}

To begin, it is useful to take note of the basic features of government debt securities. Two characteristics seem especially important to the question, which was crucial in the analysis of the previous section of whether government bonds are closer substitutes for money or for bonds.

First, both Tobin and prominent monetarists have emphasized the distinction between nominal and real claims. ${ }^{44}$ In the United States, as in most other industrialized countries, interest-bearing government debt instruments have nominal principal amounts and (except for discounted

44. See in particular Tobin, "Money, Capital, and Other Stores of Value," and Tobin, "An Essay on Principles of Debt Management." 
Table 7. Maturity Distribution of Outstanding U.S. Government Securities, End of Year, 1977

\begin{tabular}{lcc}
\hline $\begin{array}{c}\text { Maturity class } \\
\text { (years) }\end{array}$ & $\begin{array}{c}\text { Amount } \\
\text { (billions of dollars) }\end{array}$ & Percent of total \\
\hline Less than 1 & 233.0 & 50.7 \\
$1-5$ & 151.3 & 32.9 \\
$5-10$ & 45.9 & 10.0 \\
$10-15$ & 8.8 & 1.9 \\
$15-20$ & 10.9 & 2.4 \\
20 and over & 10.0 & 2.2 \\
Total & 459.9 & 100.0 \\
\hline
\end{tabular}

Source: U.S. Department of the Treasury. Figures are rounded.

bills) nominal coupons. Tobin has argued, largely on these grounds together with an assumption about the inflation-hedge property of equity returns, that interest-bearing government debt is therefore a better substitute for money than for real capital (or equity claims to real capital). Whether or not the distinction between real and nominal is the single most important determinant of relative asset substitutabilities, it clearly militates in favor of government debt as a substitute for money.

Second, Leijonhufvud and others have emphasized the length of life or duration of an asset as a primary determinant of asset-holding preferences in a world of uncertainty and incomplete contingent futures markets. ${ }^{45}$ Stiglitz and others have usefully formalized the distinction between "income uncertainty" on short-lived claims and "capital uncertainty" on long-lived claims. ${ }^{48}$ Table 7 shows the maturity distribution of the U.S. government's outstanding interest-bearing debt as of the end of 1977. The majority of the debt had a maturity of less than one year, and the mean maturity of the total debt was 36.10 months. These data cannot answer the traditional question of whether government bonds as a whole are closer substitutes for money or capital. Instead, they suggest the implausibility of the assumption that they are a perfect substitute for either one

45. Axel Leijonhufvud, On Keynesian Economics and the Economics of Keynes: A Study in Monetary Theory (Oxford University Press, 1968). The relevant concept here is not the asset's maturity but its duration; see Michael $\mathrm{H}$. Hopewell and George G. Kaufman, "Bond Price Volatility and Term to Maturity: A Generalized Respecification," American Economic Review, vol. 63 (September 1973), pp. 74953. At a yield of 6 percent a year, for example, a perpetuity has duration of about seventeen years.

46. J. E. Stiglitz, "A Consumption-Oriented Theory of the Demand for Financial Assets and the Term Structure of Interest Rates," Review of Economic Studies, vol. 37 (July 1970), pp. 321-51. 
and therefore indicate that the multiasset model developed in the previous section is a more fruitful tool of analysis than the two-asset model that would result from aggregating government bonds with either money or capital. Moreover, by showing the great diversity of maturity of the outstanding government debts, the data raise the important question of whether it is appropriate even to treat government bonds as a single aggregate.

\section{CHOOSING BETWEEN CROWDING OUT AND CROWDING IN}

If government bonds are sufficiently heterogenous that different kinds of bonds are not perfect substitutes for one another in the public's portfolio, it is potentially misleading to work with a model that treats all such bonds as identical. Although the best system of disaggregation for empirical work on portfolio behavior remains an open question, a simple distinction between "short" and "long" maturities is adequate for analytical purposes here.

A four-asset equivalent to the symmetric portfolio demand system of 19 is

(31) $\left[\begin{array}{l}M^{D} \\ S^{D} \\ L^{D} \\ K^{D}\end{array}\right]=\left[\begin{array}{c}m_{0} \\ s_{0} \\ l_{0} \\ -m_{0}-s_{0}-l_{0}\end{array}\right]$

$+\left[\begin{array}{cccc}-m_{2}-m_{3}-m_{4} & m_{2} & m_{3} & m_{4} \\ m_{2} & -m_{2}-s_{3}-s_{4} & s_{3} & s_{4} \\ m_{3} & s_{3} & -m_{3}-s_{3}-l_{4} & l_{4} \\ m_{4} & s_{4} & l_{4} & -m_{4}-s_{4}-l_{4}\end{array}\right]\left[\begin{array}{l}r_{M} \\ r_{S} \\ r_{L} \\ r_{K}\end{array}\right]$

$+\left[\begin{array}{c}m_{5} \\ s_{5} \\ l_{5} \\ -m_{5}-s_{5}-l_{5}\end{array}\right] Y+\left[\begin{array}{c}m_{6} \\ s_{6} \\ l_{6} \\ 1-m_{6}-s_{6}-l_{6}\end{array}\right] W$,

where

$S^{D}, L^{D}=$ the demands for short-term and long-term government bonds

$r_{S}, r_{L}=$ their respective expected returns

$m_{i}, s_{i}, l_{i}=$ fixed coefficients as in 19.47

Here the joint implication of the balance-sheet and symmetry constraints

47. Note that the coefficients $m_{4}$ and $m_{5}$ now have different meanings than they did in equation 19 , however. 
is that it is possible to specify completely the sixteen-element matrix with only six independent coefficients. For reasons apparent from the analysis of the previous section, it is convenient to do so in terms of the six substitution coefficients. Using 31 in place of 19 and making the corresponding change in 13 leads to a four-equation analog to 21 through 23, which determines the four variables $Y, r_{B}, r_{L}$, and $r_{K}$.

To consider the portfolio effect of the bond financing of a government deficit, it is now necessary to specify whether the bonds issued are shortterm $(d S=d G)$ or long-term $(d L=d G)$. The partial derivatives for asset-markets-only comparable to 25 and 26 can be easily derived. In the absence of any further restrictions, the results of solving the system show only that under short-term financing $\partial r_{S} / \partial G>0$ while $\partial r_{L} / \partial G$ and $\partial r_{K} /$ $\partial G$ are both of indeterminate sign, and under long-term financing $\partial r_{L} /$ $\partial G>0$ while $\partial r_{K} / \partial G$ and $\partial r_{S} / \partial G$ are of indeterminate sign. Portfolio crowding out or crowding in is possible under either short- or long-term financing. Any stronger result would be surprising, since so far the dividing line between "short" and "long" has not been specified. The securities indicated by $S$ and $L$, respectively, could be three-month and six-month bills, or they could be twenty-year and thirty-year bonds.

The analysis of the previous section provides a useful breakpoint for distinguishing short-term from long-term financing of the deficit. Here it is useful to think of "short-term" bonds as closer substitutes for money than for capital, and of "long-term" bonds as closer substitutes for capital than for money. (Both such bonds need not necessarily exist.) Once again, the relative substitutability index provides a useful metric for deciding what "closeness" means in this context. In particular, under further relative substituability conditions that imply ${ }^{48}$

$$
\sigma_{S}>\sigma^{*}>\sigma_{L},
$$

where $\sigma_{S}$ and $\sigma_{L}$ are the relative substitutability indexes of the short- and long-term bonds, defined analogously to 28 as

$$
\sigma_{S} \equiv \frac{m_{2}}{s_{4}}, \quad \sigma_{L} \equiv \frac{m_{8}}{l_{4}},
$$

48. The jointly sufficient conditions for the results stated below are

which together imply $\sigma_{s}>\sigma^{*}$, and

$$
\frac{m_{2}}{s_{8}}>\frac{m_{6}}{l_{6}} \quad \text { and } \quad \frac{s_{8}}{s_{4}}>\frac{l_{6}}{k_{6}},
$$

which together imply $\sigma_{\mathbf{L}}<\sigma^{*}$.

$$
\frac{m_{3}}{s_{3}}<\frac{m_{6}}{s_{6}} \quad \text { and } \quad \frac{s_{3}}{l_{4}}<\frac{s_{6}}{k_{6}} \text {, }
$$


and $\sigma^{*}$ is the critical value now defined analogously to 30 as

$$
\sigma^{*} \equiv \frac{m_{6}}{1-m_{6}-s_{6}-l_{6}}\left(=\frac{m_{6}}{k_{6}}\right),
$$

the results of solving the system then also show that under short-term financing $\partial r_{K} / \partial G<0$, and under long-term financing $\partial r_{K} / \partial G>0$. Financing the deficit with a short-term bond characterized by a relative substitutability index greater than $\sigma^{*}$ causes portfolio crowding in, while financing the deficit with a long-term bond characterized by a relative substitutability index smaller than $\sigma^{*}$ causes portfolio crowding out. It is also possible to achieve similar effects using a pure debt-management operation without any change in spending $(d S=-d L ; d G=0)$. Given 32, replacing long- by short-term bonds causes portfolio crowding in, while replacing short-by long-term bonds causes portfolio crowding out.

If there existed only one kind of government bond, the conclusion that there is portfolio crowding out (crowding in) according to whether that bond's relative substitutability index is greater (smaller) than $\sigma^{*}$ would be no more than a restatement of the relative substitutability condition of 29. Given the existence of different kinds of government bonds with differing substitution properties, however, these conclusions reveal the crucial importance of debt-management policy in determining the effects of fiscal policy. As long as there exists-or could be created-at least one kind of interest-bearing government debt instrument characterized by $\sigma_{S}>\sigma^{*}$ and at least one kind characterized by $\sigma_{L}<\sigma^{*}$, the government can choose whether to have portfolio crowding out or crowding in accompany its deficit spending. Under Leijonhufvud's view that the relevant substitutabilities depend primarily on the asset's length of life, the current range of maturities is probably sufficient for this purpose. Alternatively, under Tobin's view that the distinction between nominal and real denomination is of prime importance, there may be no U.S. government debt instrument capable of producing portfolio crowding out. If such an instrument did not exist, and if for some reason portfolio crowding out were the objective of policy, it could be fulfilled by the issuance of an indexed security.

Under what circumstances would the government want to use debt management to influence which effect-portfolio crowding out or crowding in-results from its deficit financing, and how much of the effect is produced? The most straightforward (though unlikely) situation would 
occur if the relevant empirical magnitudes indicated that portfolio crowding out would offset more than all of the intended effect of fiscal policy on income. In the last diagram, this would occur if the conditional $L M$ curve shifted so far leftward that $Y_{1}$ for $\sigma<\sigma^{*}$ is less than $Y_{0}$. By contrast, as long as crowding out is less than total (and especially if crowding in prevails), debt-management policy would be irrelevant if the sole objective of policy were the level of income. The more powerful the crowding out in that case, the more the government would spend to achieve a given desired income. Debt management would not matter.

When policy is concerned with both the level and the composition of income, however, debt-management policy has a major role to play along with fiscal policy. While fiscal policy alone can raise the level of income, in the absence of accelerator effects it does so at the expense of private investment. Under either transactions crowding out or portfolio crowding out, income increases because each dollar of government spending replaces a smaller-though still strictly positive-amount of private investment. When the long-term benefits of growth and productivity associated with capital formation are also criteria for policy, ${ }^{49}$ debt-management policy can minimize the crowding out (or maximize the crowding in) of investment that accompanies any given level of income. In sum, the effect of debt-management policy is to shift the trade-off between income level and composition that fiscal policy faces under an unaccommodative monetary policy.

In the context of the poor recent performance of capital formation in the United States, it is interesting to consider the debt-management policy now being used to finance the continuing large deficits shown in table 1. Table 8 presents data for the mean maturity of the U.S. Treasury's outstanding debt during the era since World War II. Subject to modest fluctuation, the dominant trend for three decades was toward a shorter mean maturity. During the late 1960s, for example-a period of unusually strong investment in plant and equipment-the mean maturity fell especially rapidly. Since January 1976 , however, debt-management policy has shifted toward sharply lengthening rather than shortening the debt. Although the quantitative effects cannot be estimated on the basis of current knowledge, it is qualitatively clear that U.S. debt-management policy

49. Such effects, including also implications for price inflation, lie outside the fixed-capital, fixed-price model used in this analysis. 
Table 8. Mean Maturity of Outstanding U.S. Treasury Marketable Securities, Selected Periods, 1946-78

\begin{tabular}{|c|c|c|}
\hline \multirow{2}{*}{$\begin{array}{c}\text { Date } \\
\text { (end of period) }\end{array}$} & \multicolumn{2}{|c|}{ Mean maturity (months) } \\
\hline & Total debt & Privately held debt \\
\hline 1946 & 112.75 & 124.17 \\
\hline 1950 & 97.11 & 99.99 \\
\hline 1955 & 65.51 & 71.24 \\
\hline 1960 & 54.84 & 58.35 \\
\hline 1965 & 59.54 & 63.31 \\
\hline 1970 & 40.43 & 40.99 \\
\hline 1975 & 33.30 & 28.90 \\
\hline January 1976 & 32.90 & 28.50 \\
\hline June 1976 & 34.68 & 31.05 \\
\hline December 1976 & 36.10 & 33.28 \\
\hline June 1977 & 38.02 & 34.48 \\
\hline December 1977 & 38.39 & 35.40 \\
\hline June 1978 & 40.52 & 36.83 \\
\hline August 1978 & 42.28 & 38.78 \\
\hline
\end{tabular}

Source: U.S. Department of the Treasury.

since 1975 has been counterproductive from the standpoint of promoting capital formation.

\section{ECONOMETRIC EVIDENCE ON PORTFOLIO SUBSTITUTABILITIES}

A fundamental implication of the models used to analyze portfolio crowding out or crowding in, both here and in the previous section, is that different nonmoney assets are not perfect substitutes. Hence the structure of relative asset yields depends upon (among other factors) relative asset supplies.

At the theoretical level, the dependence of asset yields on asset supplies has been shown in a comparative statics context by Keynes and Hicks, and in a dynamic context by Tobin. ${ }^{50}$ Culbertson and Modigliani and Sutch have expanded on this notion under the respective labels "market segmentation" and "preferred habitat," and Stiglitz has clarified how such

50. Keynes, General Theory; Hicks, "Mr. Keynes and the 'Classics'"; Tobin, "Money and Economic Growth." 
effects follow directly from investors' risk aversion (except under highly restrictive conditions on the covariance structure of the returns from individual assets). ${ }^{51}$ At the empirical level, however, for many years economists' efforts to test for the effect of asset supplies on yield relationships produced meager results at best. The standard time-series test consisted of regressing the observed spread between long and short yields directly on the relative amounts of outstanding long- and short-term treasury securities or regressing the long-term yield directly on short-term yield and relative-supply variables. Such tests rarely showed significant supply effects. ${ }^{52}$ In large part as a consequence of the accumulating evidence from these tests, economists began to lose interest in multiasset models in general, and debt-management policy in particular.

In retrospect it is possible to identify at least three reasons why such tests failed to find evidence for effects of asset supplies on asset yields, all of which are related to the unrestricted reduced-form methodology that they employed. First, these tests typically focused on "outside" or government-issued assets, implicitly relying on the assumption that intermediation is irrelevant for the structure of relative yields, so that "inside" assets (that is, debt securities issued by private borrowers) simply netted out. Second, the tests typically used only aggregative data (for example, the total amount of outside assets held by all private investors), thereby assuming implicitly that heterogeneity in portfolio behavior among different groups of investors facing different legal and institutional constraints is also irrelevant for market-determined yield relationships. Third, by using the direct reduced-form approach these tests could not impose restrictions (even on aggregate behavior) from the richly developed theory of portfolio choice.

51. J. M. Culbertson, "The Term Structure of Interest Rates," Quarterly Journal of Economics, vol. 71 (November 1957), pp. 485-517; Franco Modigliani and Richard Sutch, "Innovations in Interest Rate Policy," American Economic Review, vol. 56 (May 1966), pp. 178-97; and Stiglitz, "A Consumption-Oriented Theory."

52. See, for example, Franco Modigliani and Richard Sutch, "Debt Management and the Term Structure of Interest Rates: An Empirical Analysis of Recent Experience," Journal of Political Economy, vol. 75 (August 1967, pt. 2), pp. 569-89, and Modigliani and Sutch, "Innovations." One study that was exceptional because it did find some evidence of asset supply effects was Arthur M. Okun, "Monetary Policy, Debt Management and Interest Rates: A Quantitative Appraisal," in Stabilization Policies, prepared for the Commission on Money and Credit (Prentice-Hall, 1963), pp. 331-80. 
More recently, the seminal contribution of Brainard and Tobin has generated renewed empirical efforts to analyze the asset-substitution and other properties of portfolio behavior. Such analyses generally estimate asset-demand (and, in the context of intermediation, liability-supply) relationships analogous to systems 19 and $31 .{ }^{53}$ To date, the most successful investigations have focused on single, well-defined categories of investors, such as life insurance companies, commercial banks, or the "household" sector of the flow-of-funds accounts. To bring evidence from such models to bear on issues like those under discussion here, however, it is necessary to have a fully simultaneous model for all categories of asset holders in the economy. Alternatively, one could estimate a single system like 31 for the asset-holding behavior of the entire private sector.

Because only limited success was achieved in estimating, for use in this article, a five-asset econometric model for the aggregate U.S. nonbank private sector, reliable empirical estimates could not be provided here for the key substitution coefficients that distinguish portfolio crowding out and crowding in. ${ }^{54}$ The estimated own-yield elasticities were typically positive and significant, and the estimated cross-yield elasticities were (with one exception) either negative and significant or insignificantly different from zero. But the results as a whole did not appear to warrant even the limited confidence that might be placed in the money-demand functions used for an analogous purpose above. Given the likely importance of intermediation and investor heterogeneity, modest results for such a fully aggregated no-intermediation model are hardly surprising. ${ }^{.5}$

In the absence of such a model, one must hunt elsewhere for evidence on whether different nonmoney assets are indeed imperfect substitutes in private investors' portfolios, so that relative asset supplies do matter for relative asset yields as in the analytical models used above. Research using structural models of portfolio behavior and the determination of interest rates has provided such evidence in two forms, corresponding to the two elements of the key proposition in question. First, cross-yield elasticities are sufficiently small to indicate highly imperfect substitution among

53. Brainard and Tobin, "Pitfalls."

54. The five assets were money, time deposits, short-term treasury securities, long-term treasury securities, and equities.

55. The complete estimates, together with a description of the estimation methodology, are available from the author on request. 
nonmoney assets. ${ }^{58}$ Second, this research has found strong evidence of asset-supply effects on relative asset yields for several specific markets. ${ }^{57}$

In sum, although future research might lead to satisfactory estimates of the key substitution parameters that determine conditions like 29 and 32, even the limited evidence now available appears to deny the assumption of perfect (or nearly perfect) substitutability of nonmoney assets that would preclude portfolio crowding in and render debt-management policy irrelevant.

\section{SUMMARY}

Several useful conclusions about the effects of debt-financed government deficits emerge from extending the analysis to take account of the observed heterogeneity within the single-asset category of "government bonds."

The nominal returns on government debt instruments, together with their relatively short average maturity, suggest strongly that they are not perfect substitutes for real capital. They do not appear to be perfect substitutes for money either, however.

The range of different maturities actually or potentially available strongly suggests that all government debt instruments are not even perfect substitutes for one another. It is the government's prerogative of choosing among them that facilitates debt-management policy.

As long as there exists (or could be created) at least one government debt instrument (a short-term bond) with a relative substitutability index

56. See Benjamin M. Friedman, "Financial Flow Variables and the Short-Run Determination of Long-Term Interest Rates," Journal of Political Economy, vol. 85 (August 1977), pp. 661-89; and Roley, "A Structural Model." Other researchers have found similar evidence for imperfect substitutability among liquid assets; see, for example, R. W. Kopcke, "U.S. Household Sector Demand for Liquid Financial Assets, 1959-1970," Journal of Monetary Economics, vol. 3 (October 1977), pp. 409-41.

57. See Friedman, "Financial Flow Variables," on the corporate bond market, and Roley, "A Structural Model," on markets for short and intermediate-term treasury notes and long-term treasury bonds. Other researchers have found evidence for asset-supply effects in models that encompass more asset markets but are less specific about the nature of the asset substitutions involved; see, for example, Barry Bosworth and James S. Duesenberry, "A Flow of Funds Model and Its Implications," in Issues in Federal Debt Management (Federal Reserve Bank of Boston, 1973), pp. 39-147; and Patric H. Hendershott, Understanding Capital Markets, vol. 1: A Flow-of-Funds Financial Model (Heath, 1977). 
greater than the key ratio of the respective wealth responses of money and capital and at least one (a long-term bond) less than the ratio, debtmanagement policy can determine which effect-portfolio crowding out or crowding in-results from financing deficits, and how much. Longterm financing leads to crowding out, while short-term financing leads to crowding in.

The most important role for debt-management policy is to shift the trade-off between raising total income and reducing private investment that is faced by fiscal policymakers under an unaccommodative monetary policy. Viewed in this context, the change in U.S. debt-management policy that began after 1975 has been counterproductive from the standpoint of promoting capital formation.

The available empirical evidence does not support the contention that familiar nonmoney assets-like bonds and equities or short- and longterm bonds-are perfect substitutes. Hence portfolio crowding in can occur, and debt-management policy does matter.

\section{Conclusions for Fiscal, Debt-Management, and Monetary Policies}

The principal conclusion of this article-that the consequences of bond financing (and of transactions crowding out) do not appear as damaging for expansionary fiscal policy as previous analysis has indicated-suggests that the assessment of fiscal policy actions should start with the behavior of the real sector rather than that of the financial sector. Offsets from the shift or slope of the $L M$ curve need not vitiate the efficacy of fiscal policy. Rather, both the availability of real resources to meet additional demand for real spending and the likelihood of an induced expansion of productive capacity constitute potentially more restrictive conditions for effective fiscal stimulation. Practical analysis for policymaking purposes is even more difficult because most of the available evidence indicates that both the response of price inflation to aggregate demand pressure and the response of fixed investment to anticipations of changing rates of return involve substantial time lags. Deciding the case for or against fiscal stimulation on a race between inflation and the accelerator is a crude, but not altogether inaccurate, conceptualization of the problem. If fiscal policy is necessarily ineffective in a given situation, it is likely to be so because of those effects in the goods market and 
not because of problems caused in the financial markets by an excess supply of bonds.

The second conclusion is that debt management, despite the lack of attention paid to it in almost any recent discussion of macroeconomic policy, is an essential part of the story. The portfolio behavior that follows the issuance of government bonds need not vitiate the intended effect of fiscal policy, although under improper debt-management policy it almost certainly can. The case for or against lengthening the average maturity of the U.S. public debt, as the Treasury has recently done, rests on arguments that lie well beyond the scope of this article. What does seem clear, however, is that the recent period, which has witnessed extraordinarily large federal deficits and a sluggish recovery of capital spending, has been a particularly unpropitious time for such a debt-restructuring program. The Treasury should be meeting its financing requirements during this period in such a way that it denies, not satisfies, the demands of investors for long-term securities, thereby stimulating the public to turn to the corporate business sector for more new issues. The fact that the Treasury has been able to issue its long-term bonds without causing "indigestion" in the debt markets is beside the point. The objective of debt-management policy should have been to keep the market hungry for long-term assets, not merely to avoid overfeeding it.

It is useful to recall that this entire analysis has proceeded on the assumption of a strictly unaccommodative monetary policy. This need not be the case; in practice the Federal Reserve System has often adopted at least a partially accommodative stance in the face of a decision by Congress and the executive branch to pursue a policy of fiscal stimulation. A responsive monetary policy would have a major impact on the issues analyzed here in two ways. First, increasing the money stock would cause an expansionary shift in the $L M$ curve. Second, even with no change in monetary growth, the Federal Reserve can influence the economic consequences of debt-financed fiscal policy by the simultaneous purchase of long and sale of short treasury securities (or vice versa) through its openmarket operations. Although only the Treasury can design and issue a new security (such as an indexed bond or a perpetuity), the Federal Reserve's portfolio is sufficiently large to exert a substantial impact on the composition of the outstanding securities issued by the Treasury. If debtmanagement policy fails to pursue a path consistent with the objectives of fiscal policy, monetary policy can provide a satisfactory surrogate. 


\section{Comments and Discussion}

Stephen M. Goldfeld: This is a useful and eminently readable paper. It treats a number of important issues that have been around for a while, but Friedman manages to pull them together in a quite neat way. There are several major topics covered in the paper and I will say a few words about each.

The first issue is that of transactions crowding out. Friedman's main contribution here is in providing some estimates of the degree of crowding out, while indicating the potential need for a term-structure adjustment when long-term rates enter the $I S$ curve but short-term rates enter the $L M$ curve. There is one minor technical inelegance in the calculations-the use of elasticity estimates, stemming from log-linear $L M$ and $I S$ curves, is not quite reconciled with Friedman's development based on a linear model. However, the effect of this is probably small. There is also an asymmetry of sorts-Friedman computes the degree of crowding out for alternative estimates of the $L M$ curve but for only one estimate of the IS curve. Because there is hardly unanimity on spending elasticities, it would be nice to know the sensitivity of the results to alternative IS curves. In this regard, some evidence available from simulations of existing econometric models could be brought to bear. The one virtue of these, as opposed to the estimates Friedman reports, is that they cope with a variable price level and take account of the cyclical state of the economy, both of which are factors that should influence the extent of transactions crowding out.

The second topic covered in the paper, and really the most important one, is the discussion of portfolio crowding in or crowding out. Friedman derives a simple, understandable result in terms of the coefficients of the asset-demand equations and makes clear what empirical magnitudes are 
necessary for deciding in favor of crowding in or crowding out. It should, of course, be noted that the specific formula that is obtained is quite dependent on a number of strong assumptions about specification. These include linearity of the asset-demand functions in interest rates, income, and wealth; and symmetry of the interest rate coefficients across equations. Relaxing these assumptions would clearly change the formula but would not affect the main point. In fact, a recent paper by Cohen and McMenamin, referred to by Friedman, arrives at qualitatively similar results in the context of a model with somewhat different functional specifcations.

Functional details aside, there is another sense in which Friedman's setting is restrictive: it is a static one-period story. While that is the simplest way to clarify what is occurring, it does leave out some potentially important features. There is, for example, the question of stability as originally examined by Blinder and Solow. The Cohen and McMenamin paper mentioned above does examine this question and finds problems of stability when bonds are close substitutes for equities. I assume the same difficulty would arise in a dynamic version of Friedman's model so that one should probably not take too seriously the case where portfolio crowding out leads to a negative fiscal multiplier.

Another dynamic aspect which is missing is that portfolio crowding in or crowding out in the real world is not a timeless phenomenon. One has to be precise about the relevant horizon because it is easy to construct situations in which portfolio crowding in prevails over one time period and crowding out over another. Indeed, the presence of lags in the kinds of asset-demand equations alluded to in the latter part of the paper could well, as an empirical matter, produce this result. A related point concerns the treatment of the various interest rates. Once one moves beyond the one-period model or undertakes empirical work, the relevant interest rates are holding period yields. Furthermore, the relevant yields may differ in the asset equations and in the $I S$ sector. As a consequence, considerable effort may be necessary to define "the" bond rate or "the" equity rate.

Taken as a whole, these considerations suggest that a complete condition for portfolio crowding in or crowding out will be somewhat more complicated than Friedman's formula and, further, that empirical evaluation of any such formula is no simple task.

A third issue Friedman addresses is the role of wealth in the demand function for money. In the absence of a wealth variable, portfolio crowd- 
ing out cannot occur. To preserve this possibility, Friedman seeks to demonstrate the statistical significance of a wealth variable. (For crowding out to emerge, the wealth effect would have to be "large" and not just statistically significant, but this issue is not addressed.) While I believe a plausible case can be made for a statistically significant wealth effect, I do not consider the evidence Friedman offers particularly persuasive. He observes that, while wealth is insignificant in a basic moneydemand function estimated through 1972, extending the sample period to 1977 makes wealth "work." However, this equation hardly forms the basis for a strong case: it fails a stability test, and has some quite strange parameter estimates. Friedman does report that an equation including wealth but excluding income is stable and that at least one version of such an equation extrapolates well in the post- 1972 period. This, however, is not a serious specification because, as Friedman notes, the issue is not whether to exclude income but rather whether to include wealth. Furthermore, the wealth-only equations have implausibly slow speeds of adjustment and, as I have found, perform terribly in out-of-sample extrapolations for earlier sample periods. It seems, then, that there is no fully satisfactory equation exhibiting a significant wealth effect.

Some evidence exists, however, to support Friedman's case in my 1976 paper in $B P E A$, which Friedman cites. There, I reported that a nominal adjustment model in per capita terms exhibited both significant wealth and income variables, even if the sample period stopped in 1973. Furthermore, the various details contained in tables 7 and 8 of that paper show that in extrapolations starting as early as 1966 , the equation with wealth and income forecasted better than the equation with income alone. I did not develop these results because I was focusing on the post-1973 experience and there, as is evident from Friedman's results, the equation with wealth and income is not satisfactory. On the whole, I would regard this earlier evidence as bolstering Friedman's case, although to me the recent period remains somewhat of a puzzle.

Friedman does note these issues in his discussion of Michael Hamburger's results, and I should like to indicate briefly why I do not think Hamburger has solved the recent money puzzle. The main wrinkle in Hamburger's equation seems to be the use of two long-term rates of return, including the dividend-price ratio. Friedman, in fact, improves on the extrapolative performance of this equation by substituting wealth for the dividend-price ratio. I believe, however, that neither Hamburger's 
original equation nor Friedman's modification stand up to close scrutiny since the real reason these equations work is that they constrain the income elasticity to unity. This serves to drive up the coefficient of the lagged money stock (that is, lower the speed of adjustment) by a substantial amount, something that tends to happen to the "basic" equation as it falls apart (see Friedman's table 4). It is therefore not surprising that this kind of restriction tends to produce a better forecast. Unfortunately, the restriction is not valid because the hypothesis of the unitary income elasticity is readily rejected by the data through 1973 . Furthermore, when this restriction is relaxed in the context of Hamburger's specification, the resulting equation both fails a stability test and forecasts poorly. On balance, then, I am not persuaded that the wealth variable has a major role to play in understanding the recent behavior of money demand.

My final brief comment is on the policy role for debt management posited in the last part of the paper. The argument makes good sense, but I doubt that the empirical magnitudes warrant much of a practical role for debt management. The evidence offered linking changes in the maturity of the federal debt and the recent behavior of investment, while interesting, seems circumstantial at best. Furthermore, because of problems in coping with the need for expectations in constructing holding period yields, this is a difficult problem on which to get solid empirical evidence. Nevertheless, Friedman himself has already done important work in this area and should be encouraged to carry out further research along the lines he indicates at the end of the paper.

John H. Kareken: Friedman has given us a thorough appraisal of the claim that "debt-financed deficits 'crowd out' interest-sensitive, privatesector spending," and we should all, I think, feel indebted to him for it. As he suggests in his paper, though, for those who are sure that price stability is desirable, there is another argument against government deficits, even those financed by bond issues. In his words, it is that "what matters for prices is not only the money stock but some combination of money plus the outstanding interest-bearing government debt." And because Friedman has been so thorough in his appraisal of the "crowding-out" argument, I will spend the time allotted me on that possibility. That may be irresponsible, but I do not think so. The routine of the Brookings panel is after all a little curious, at least in one regard. Not long ago I gave 
Friedman my criticisms of his first draft, and I am quite willing to accept his appraisal of them, as revealed by the changes he saw fit to make.

In his paper Friedman remarks that of late no one has taken at all seriously, to the point of carefully examining it, the possibility that how government deficits are financed is of no consequence. His explanation is that the monetarist tide has been running too strong. But Friedman is not exactly right. My colleague Neil Wallace has considered the possibility. The paper in which his analysis appears, "The Overlapping Generations Model of Fiat Money," has not yet been published, or indeed even widely circulated, so Friedman can hardly be chided for not having been more diligent in his search of the literature.

What Wallace shows in his paper is that, to a first approximation, it matters not at all how the government deficit is financed. The size of the deficit certainly matters; but how it is financed, whether by issuing bonds or by printing more money, does not. To rephrase Wallace's result, open market operations amount to nothing (or little) more than central bank busy work. That, it seems to me, is right, and what I thought I would do now, if without much hope of convincing anyone, is to give a loose paraphrase of the proof of that proposition. I want to be clear that the paraphrase is mine alone. Wallace may have bungled badly, but no one should conclude that before perusing his paper.

To isolate the effects of an open market operation, it is necessary to hold fiscal policy constant. On that, I believe, there is general agreement. For a single economy of the sort I have in mind, it suffices to hold the government budget deficit (or, more accurately, the time path of the deficit) unchanged. Because government spending has a social optimum, transfer payments and tax receipts, or the net thereof, must therefore be adjusted in such a way as to offset any change in the government's net worth that results from the open market operation. With a properly defined or truly ceteris paribus open market operation, the net worth of the government is unchanged. But it follows that, in effect, the balance sheet of individuals is also unchanged. And in consequence the equilibrium of the economy is unaltered. With the balance sheet of individuals unchanged, or in effect unchanged, future-period consumption options are precisely what they were, and therefore the current-period equilibrium is precisely what it was. Not even the price level changes as a result of an official asset exchange. That is the inevitable result of assuming, reason- 
ably enough, that for money, as for all other assets, the essential question is "What rate of return does it offer?"

An example may be helpful. Imagine a two-asset economy with, say, real capital in the form of a storable consumption good, and paper money, the liability of the government. And suppose for definiteness that the government, engaging in an open market operation, increases the amount of capital it owns and perforce its money indebtedness. Since its budget deficit cannot change, it must transfer back to individuals whatever change in its net worth is implied by the assumed exchange. The transfer payments must be distributed appropriately. The distribution of income cannot change with an open market operation. If it did, fiscal policy would not be unchanged. Equally obvious, the transfer payments may be negative. If the capital acquired by the government is risky, as it must be for portfolio diversification, there may be an implied decrease in net worth, and it may therefore be required that individuals be taxed.

For an unchanged government deficit it is necessary that transfer payments depend on the current state of the world. That observation is basic, and explains why, whatever appearances may be, the balance sheet of individuals does not really change. Because the government must return whatever it earns on any increment of capital (or, more generally, earning assets) that it acquires, the amount held by individuals does not really decrease. Nor in effect is there any increase in the real balances owned by individuals.

The conventional analysis goes astray in concentrating on seeming changes, on changes that disappear with the necessary adjustments that keep the net worth of government constant. It takes seriously that the money held by individuals increases when, for example, the government buys back some of its bonds. But that increase is, in a word, fictitious. I can put the argument another way. One gets the right answer to the question "what happens when the government engages in an open market operation?" by looking at the consolidated balance sheet of individuals and government. Clearly, whatever assets are exchanged by the government and individuals, that balance sheet remains what it was.

Or to put the argument yet another way, individuals pierce the veil of government. They are forced to do that by the required adjustment in transfer payments. In the world of Franco Modigliani and Merton Miller, conjured up a couple of decades ago, individuals pierce the corporate 
veil, if perhaps not quite in the same way that judges have. And in Wallace's world, individuals pierce the government veil. What Wallace has given us then is Modigliani and Miller all over again. The corporations of the world of Modigliani and Miller are financial intermediaries, and so is the government of Wallace's world.

As might be expected, the conclusions that open market operations are pointless is not perfectly general. An official asset exchange of sufficient magnitude can change the equilibrium price of money. If the government acquires more capital than individuals would have, individuals will want less money, and the price of money will therefore adjust. That is not to say, though, that the traditional analysis is right. Moreover, as John Bryant and Wallace have shown, if there is a reserve requirement, then how the government is financed does matter. ${ }^{1}$ And depending on what government and private transactions costs are, it may. But that there may be more or less deadweight loss, depending on how a given fiscal policy is financed, is not the traditional conclusion, and it would seem reasonable that as a practical matter macroeconomists can safely ignore whatever changes in deadweight loss result from open market operations.

Before stopping I want to anticipate a couple of possible objections to what I have said. The first can be cast in question form. What about all those studies which show that money and prices move together? The difficulty is, though, that many of the most dramatic changes in the money supply were not produced by official asset exchanges. A coinage debasement is not an open market operation. The discovery of gold in Mexico was not. The several U.S. banking panics were not. There is all the difference in the world between an open market operation and a change, however brought about, in private wealth. All the simple regression studies that have been done can therefore simply be dismissed. And the evidence from multiple regression studies is hardly more impressive. There are few if any that are not subject to Robert Lucas' criticism. I know of none.

The other possible objection, which does have to be taken more seriously, is that of the overlapping generations or money-as-a-store-of-value

1. See John Bryant and Neil Wallace, "The Inefficiency of a Nominal National Debt," staff report 28 (Federal Reserve Bank of Minneapolis, 1977) (Journal of Political Economy, forthcoming); and Bryant and Wallace "Open Market Operations in a Model of Regulated, Insured Intermediaries," staff report 34 (Federal Reserve Bank of Minneapolis, 1978). 
model. Allegedly, it can deliver only half-truths. In the real world, so the argument goes, money serves both as a store of value and as a medium of exchange. But in the world of overlapping generations, it serves only as a store of value. Unfortunately, there is no time to argue the issue. All I can do is say that I believe the criticism is wrong. I would grant though, that until someone has managed the near-impossible, until someone has modeled a world of more or less continuous exchange of goods and money, we will not be quite sure about the overlapping generations model or the radical conclusions that it yields.

Michael Hamburger: I liked Friedman's paper, particularly because it examined the relative degree of substitutability among different assets. The relative substitutability issue is a way of gaining insight into the debate over monetarism, because monetarists believe that money is a substitute for a wide range of both financial and real assets, while nonmonetarists confine the range of money substitutes to a narrow range of short-term financial assets. I was disappointed, however, that the paper did not advance our empirical knowledge on the substitutability question. All the money-demand equations estimated by Friedman contain only two interest rates, both yields on nominal financial assets. He goes to great pains to argue that the return on the real asset that I used-the dividend-price ratio-served primarily as a proxy for the price of equities or wealth. That claim is not supported by other work I have done on U.S. money-demand equations for a variety of periods or on similar equations for the United Kingdom, in which this ratio was a better explanatory variable than was the price of equities or wealth.

The analysis of the effects of putting wealth in the money-demand function is also important. According to Stephen Goldfeld's discussion, his finding that wealth is not a significant explanatory variable stems largely from the 1950s and early 1960s. Friedman's results raise doubts about the generality of these findings and thus tend to support Brunner and Meltzer on the importance of wealth in the money-demand function.

I would be interested in seeing the results Goldfeld discussed which, in his view, suggest that my analysis solves the recent money puzzle only because the income elasticity is constrained to unity. Without examining his findings, I can only report that the constraint on the nominal income elasticity is not binding; when it is estimated freely, it comes out to be almost exactly unity. Moreover, although the real income elasticity is 
significantly less than one during the sample period, this finding has no important effect on the out-of-sample residuals. Hence, the results I am aware of indicate that the solution to the post-1974 money puzzle is not dependent on the constraint on the income elasticity of money demand. If others have different results, I would like to see them.

Finally, contrary to Friedman, I hope that we do not try to establish debt-management policy as an important element of stabilization policy in the United States. The unhappy British experience of using monetary policy largely for debt-management purposes should warn us against such a course. In addition, there is a great deal of evidence that changes in the composition of debt do not have much effect. It seems noteworthy that the average maturity of the debt rose substantially during periods such as the mid-1960s, which were excellent ones for real investment.

\section{General Discussion}

Friedman addressed some comments to his formal discussants. He first observed that, at least according to John Kareken's presentation, the paper by Neil Wallace had finally supplied the thesis that "money does not matter." Since the recent positions in the profession range from "only money matters" to "money also matters," the Kareken position clearly expands the spectrum of views on the efficacy of monetary policy. Friedman said that he hoped that people who advanced the view that income is determined by bonds plus money would recognize their disagreements with monetarists who see income determined by money alone.

Friedman agreed with Goldfeld on the point that, in principle, expected holding period yields-that is, yields that included expected changes in asset prices-rather than measured yields ought to be in assetdemand functions, and with Michael Hamburger's view that the yields on a wide spectrum of assets should appear in the money-demand function. In fact, in empirical work carried out for the paper and mentioned but not reported, he had attempted (with only partial success) to relate money demand to the expected holding-period yields, adjusted for inflation, on money itself and four alternative assets.

Saul Hymans felt that Friedman had provided a valuable exposition of the framework for analyzing crowding out and crowding in. He added 
that crowding in was the long-run prediction of the Michigan model, which specified a demand function for liquidity aggregating money and bonds. As Hymans saw it, his work suggested that bonds are a closer substitute for money than they are for capital, and hence that crowding in prevailed.

Other discussants, however, introduced a variety of reasons why crowding in might be less likely than Friedman's paper implied. Rudiger Dornbusch, George von Furstenberg, and Frederic Mishkin all questioned the implicit assumption of the paper that financial effects on investment demand depended solely on changes in the return on capital. They pointed out that, if investment demand were linked to the cost of capital (equity and debt) or to James Tobin's $q$, which reflected both equity and debt valuation, higher bond yields associated with financing deficits would show up as a greater depressant of investment, thus decreasing the probability of crowding in. Friedman agreed that, in a complete model including private debt and corporate equities, the investment-demand function would be linked to both corporate bond and equity yields. He explained that he had simplified the analysis for expositional purposes by adjusting for debts within the private sector, and he argued that the simplification did not alter the qualitative considerations affecting crowding in or crowding out. Arthur Okun supported Friedman's response, suggesting that his verdict could be upset only if bonds and real capital were gross complements-which seemed highly unlikely.

Von Furstenberg remarked that the short-run character of Friedman's analysis biased the result toward crowding in. The paper focused on a situation in which the volume of government bonds increases, while the quantities of money and capital are unchanged. In that situation, it is not surprising that the required return on capital is likely to decline. But von Furstenberg argued that, in such a case, the government neither absorbs cash nor uses resources, merely distributing bonds to the public as gifts (or creating a "rainshower" of bonds). In an actual deficit operation, however, the quantity of capital can remain unchanged in the face of government dissaving only if that dissaving is offset fully by extra private saving. For the actual deficit operation, von Furstenberg expressed his judgment that crowding in was at most a "curiosity." Friedman countered that he saw no problem in assuming that, for the short-run, extra private saving offset the government dissaving-indeed that was consistent with 
standard models of income determination. He agreed, however, that an analysis of the long-run consequences had to rely on a dynamic model taking account of other considerations affecting capital formation.

Edmund Phelps elaborated on some of the distinctions and interrelationships between short-run and longer-run adjustments. For the short run, he felt that an unanticipated antirecessionary increase in public expenditure might exert its primary stimulative effect on inventory investment, fixed investment being largely predetermined for quite a while. But if an addition to public expenditure is expected to persist over the long run and to have ultimately an unfavorable impact on fixed capital formation, that adverse expectation may affect the short run. Under those conditions, the stock market might fall promptly, and thus fixed investment might be dampened rather than stimulated in the near term.

Michael Wachter and Martin Feldstein suggested that crowding in would appear less likely in a more realistic model that took into account supply constraints and some degree of price flexibility. Wachter surmised that the various elasticities might be different at various stages of the cycle, shifting toward the crowding out result in periods of high utilization. Feldstein stressed that price flexibility strengthened the traditional mechanism of crowding out: the inflation generated by fiscal stimulus would reduce real monetary balances. Friedman agreed that the supply side effects from which he had abstracted would push toward crowding out; but he noted that he had also abstracted from accelerator effects on investment that would push toward crowding in.

The discussion also focused on the policy implications of Friedman's analysis. Dornbusch doubted that changing the maturity structure of the federal debt could be an effective policy, and cited evidence that shortterm and long-term securities are highly substitutable. Franco Modigliani shared that view, and reported on his analysis of the one historical attempt to affect interest rates through debt management, the so-called operation twist. He had found that the changes in the relative supplies of long-term and short-term debt had had no effects. Moreover, this was fortunate since actually operation twist had lengthened, rather than shortened, the maturity of the debt-accomplishing the opposite of what had been intended. Friedman noted, however, that the recent degree of lengthening of the debt was considerably larger than that during operation twist. He stressed furthermore that both Modigliani's research and that mentioned by Dornbusch had used an unrestricted reduced-form meth- 
odology in contrast to the richer structural approach adopted in his own and Roley's work that had found much lower estimated elasticities of substitution.

Modigliani was also unconvinced that wealth played an important role in the money-demand function. He agreed with Goldfeld's interpretation of the empirical results. Furthermore, he stressed that the demand for money in recent years should be overpredicted by any function not explicitly allowing for recent innovations in banking that had facilitated economizing on demand deposits. Thus he was skeptical of any equation that fitted well without allowing for these institutional changes. Moreover, he saw no analytical reason for wealth to influence money demand. Friedman countered that portfolio shifts generate a transactions demand for cash, and their magnitude had to be related to the total size of portfolios; that alone could account for the small, although significant, wealth elasticity he had found.

Robert Hall suggested that the paper presented an overly optimistic view of fiscal policy by underestimating the interest elasticity of investment demand. He contrasted Friedman's use of differing estimates of the interest elasticity of the demand for money with his concentration on a single estimate of that of investment demand. Hall considered that estimate implausibly low. Estimates of the interest-elasticity of investment demand that seemed more accurate to Hall implied that fiscal policy would have little efficacy. Friedman mentioned a paper by Olivier Blanchard that had obtained similar empirical results to his on the interest elasticity of investment while using an analytical approach more sympathetic to Hall's. But he felt that professional knowledge of that magnitude was weak and identified it as an important item on the agenda for future research.

Speaking of other research needs for the future, William Brainard emphasized the difficulty of estimating the required rate of return on capital, which is important in determining the relative substitutability among assets relevant to the crowding-out question. The valuation of corporations reflects the "expected marginal product of capital"-profit expectations, taxes and the like as well as the required return on real capital. It is difficult to distinguish changes in the required return from changes in these other factors affecting market valuation. He also indicated that his joint work with Tobin, which used panel data to study the determinants of the valuation of firms, suggested substantial year-to-year changes in the 
required return on capital and a looser relationship than is typically assumed between this rate and the rates of return on financial assets.

William Poole pointed out that the typical discussion of fiscal policy ignored the effect of inflation in reducing the real value of the federal debt. When the real capital losses of bondholders are taken into account, it becomes evident that fiscal policy has been much less stimulative in recent years than it appears when viewed in purely nominal terms. Modigliani strongly supported Poole's point, and emphasized that the national income accounts should be adjusted to reflect it: a major portion of government interest payments does not really represent income, but is merely a restitution of the real principle of bondholders. George Jaszi said that, while it was potentially an important economic phenomenon, the estimation of the inflation premium in federal interest payments posed analytical issues that lay outside the scope of accounting procedure.

Michael Boskin noted a number of other measurement and conceptual issues about the public debt. In principle, as he saw it, the key fiscal variable is the debt of total government-federal, state, and local-and that total has been declining relative to GNP in recent years. He also identified as an important unsettled issue the appropriate treatment of the implicit debts associated with government commitments for future benefits in social insurance programs. 